\title{
Carbon dioxide inhibits COVID-19-type proinflammatory responses through extracellular signal-regulated kinases 1 and 2, novel carbon dioxide sensors
}

\author{
Hanna Galganska ${ }^{1} \mathbb{D} \cdot$ Wieslawa Jarmuszkiewicz ${ }^{2} \mathbb{D} \cdot$ Lukasz Galganski $^{\mathbb{D}}$
}

Received: 8 May 2021 / Revised: 4 October 2021 / Accepted: 21 October 2021 / Published online: 6 November 2021

(c) The Author(s) 2021

\begin{abstract}
Mitogen-activated protein kinase (MAPK) signalling pathways are crucial for developmental processes, oncogenesis, and inflammation, including the production of proinflammatory cytokines caused by reactive oxygen species and upon severe acute respiratory syndrome coronavirus 2 (SARS-CoV-2) infection. There are no drugs that can effectively prevent excessive inflammatory responses in endothelial cells in the lungs, heart, brain, and kidneys, which are considered the main causes of severe coronavirus disease 2019 (COVID-19). In this work, we demonstrate that human MAPKs, i.e. extracellular signalregulated kinases 1 and 2 (ERK1/2), are $\mathrm{CO}_{2}$ sensors and $\mathrm{CO}_{2}$ is an efficient anti-inflammatory compound that exerts its effects through inactivating ERK1/2 in cultured endothelial cells when the $\mathrm{CO}_{2}$ concentration is elevated. $\mathrm{CO}_{2}$ is a potent inhibitor of cellular proinflammatory responses caused by $\mathrm{H}_{2} \mathrm{O}_{2}$ or the receptor-binding domain (RBD) of the spike protein of SARS-CoV-2. ERK1/2 activated by the combined action of RBD and cytokines crucial for the development of severe COVID-19, i.e. interferon-gamma (IFN $\gamma$ ) and tumour necrosis factor- $\alpha$ (TNF $\alpha$ ), are more effectively inactivated by $\mathrm{CO}_{2}$ than by dexamethasone or acetylsalicylic acid in human bronchial epithelial cells. Previously, many preclinical and clinical studies showed that the transient application of $5-8 \% \mathrm{CO}_{2}$ is safe and effective in the treatment of many diseases. Therefore, our research indicates that $\mathrm{CO}_{2}$ may be used for the treatment of COVID-19 as well as the modification of hundreds of cellular pathways.
\end{abstract}

Keywords ERK1 $\cdot$ ERK2 $\cdot$ Interleukin- $6 \cdot$ Hydrogen peroxide $\cdot$ Bicarbonate $\cdot S$ protein

\begin{tabular}{|c|c|c|c|c|}
\hline \multicolumn{3}{|c|}{ Abbreviations } & ECs & Endothelial cells \\
\hline \multicolumn{2}{|c|}{$\mathrm{AC}$} & Adenylyl cyclase & EGM-2 & Endothelial cell growth medium-2 \\
\hline \multicolumn{2}{|c|}{ ACE2 } & Angiotensin-converting enzyme 2 & EGM-2 MV & Microvascular endothelial cell growth \\
\hline \multicolumn{2}{|c|}{$\mathrm{BCI}$} & (E/Z)-BCI hydrochloride & & medium-2 \\
\hline \multicolumn{2}{|c|}{$\mathrm{CO}_{2}$} & Carbon dioxide & ELISA & Enzyme-linked immunosorbent assay \\
\hline \multicolumn{2}{|c|}{ COVID-19 } & Coronavirus disease 2019 & ERK1/2 & Extracellular signal-regulated kinases 1 and \\
\hline \multicolumn{2}{|c|}{$\operatorname{dex}$} & Dexamethasone & & 2 \\
\hline \multicolumn{2}{|c|}{ DMSO } & Dimethyl sulfoxide & FastAP & Fast alkaline phosphatase \\
\hline$凶$ & \multicolumn{2}{|c|}{$\begin{array}{l}\text { Wieslawa Jarmuszkiewicz } \\
\text { weslawa.jarmuszkiewicz@ amu.edu.pl }\end{array}$} & $\begin{array}{l}\text { GC } \\
\text { HIF- } 1 \alpha\end{array}$ & $\begin{array}{l}\text { Guanylyl cyclase } \\
\text { Hypoxia-inducible factor } 1 \text { alpha }\end{array}$ \\
\hline$\Delta$ & \multicolumn{2}{|c|}{ Lukasz Galganski } & HPMECs & $\begin{array}{l}\text { Human pulmonary microvascular endothe- } \\
\text { lial cells }\end{array}$ \\
\hline & & & HUVECS & Human umbilical vein endothelial cells \\
\hline & \multirow{3}{*}{\multicolumn{2}{|c|}{$\begin{array}{l}\text { Molecular Biology Techniques Laboratory, Faculty } \\
\text { of Biology, Adam Mickiewicz University, Uniwersytetu } \\
\text { Poznanskiego 6, 61-614 Poznan, Poland }\end{array}$}} & ICAM-1 & Intercellular adhesion molecule 1 \\
\hline & & & $\mathrm{IFN} \gamma$ & Interferon-gamma \\
\hline & & & IL-6 & Interleukin-6 \\
\hline & \multirow{3}{*}{\multicolumn{2}{|c|}{$\begin{array}{l}\text { Laboratory of Mitochondrial Biochemistry, Department } \\
\text { of Bioenergetics, Faculty of Biology, Adam Mickiewicz } \\
\text { University, Uniwersytetu Poznanskiego 6, 61-614 Poznan, } \\
\text { Poland }\end{array}$}} & IP_C & Immunoprecipitation control \\
\hline & & & JNK & C-Jun N-terminal kinase \\
\hline & & & LPS & Lipopolysaccharides \\
\hline
\end{tabular}




\begin{tabular}{|c|c|}
\hline MAPK & Mitogen-activated protein kinase \\
\hline MBP & Myelin basic protein \\
\hline MEK & MAPK kinase \\
\hline MKP & MAPK phosphatase \\
\hline MSK1 & $\begin{array}{l}\text { Mitogen- and stress-activated protein kinase } \\
1\end{array}$ \\
\hline NFкB & $\begin{array}{l}\text { Nuclear factor kappa-light-chain-enhancer } \\
\text { of activated B cells }\end{array}$ \\
\hline PBS & Phosphate-buffered saline \\
\hline PBST & PBS with $0.1 \%$ Tween-20 \\
\hline $\mathrm{pCO}_{2}$ & Partial pressure of $\mathrm{CO}_{2}$ \\
\hline RBD & $\begin{array}{l}\text { Receptor-binding domain of the SARS- } \\
\text { CoV-2 spike protein }\end{array}$ \\
\hline ROS & Reactive oxygen species \\
\hline $\mathrm{TNF} \alpha$ & Tumour necrosis factor- $\alpha$ \\
\hline SD & Standard deviation \\
\hline $\mathrm{TCID}_{50}$ & Tissue culture infectious dose 50 \\
\hline
\end{tabular}

\section{Introduction}

The physiological importance of carbon dioxide $\left(\mathrm{CO}_{2}\right)$ in tissues, organs and the body is well understood. However, the influence of this common gas on the functioning and components of cells is poorly understood, even though all cells in which organic substances are oxidised in the processes of oxidative cellular respiration produce $\mathrm{CO}_{2}$. While $\mathrm{CO}_{2}$, as a small molecule, can be efficiently transported through membranes by diffusion, $\mathrm{CO}_{2}$ is spontaneously hydrated to $\mathrm{HCO}_{3}{ }^{-}$at the $\mathrm{pH}$ of the cytoplasm. Carbonic anhydrases can convert $\mathrm{HCO}_{3}{ }^{-}$to $\mathrm{CO}_{2}$ and vice versa. The widespread presence of carbonic anhydrases in bacteria, archaea and eukaryotes and the existence of additional $\mathrm{CO}_{2}$ and $\mathrm{HCO}_{3}{ }^{-}$transporters indicate the benefits of rapid regulation of $\mathrm{CO}_{2}$ levels in cells, further suggesting the importance of $\mathrm{CO}_{2}$ for cell functions. It is, therefore, expected that there are mechanisms of $\mathrm{CO}_{2}$ sensing that are common to different groups of organisms. However, conserved $\mathrm{CO}_{2}$ receptors have not yet been found, and the currently identified eukaryotic $\mathrm{CO}_{2}$ sensors are specific to only particular groups of organisms, e.g. insect chemoreceptors. In mammals, several families of proteins are considered $\mathrm{HCO}_{3}{ }^{-}$receptors, including protein tyrosine phosphatases, which are inactivated by $\mathrm{HCO}_{3}{ }^{-}$-assisted oxidation using $\mathrm{H}_{2} \mathrm{O}_{2}$ [1], adenylyl cyclases (ACs) [2] and guanylyl cyclases (GCs) [3].

Mitogen-activated protein kinases (MAPKs) have been found in all eukaryotes. They regulate many aspects of cell survival, proliferation, differentiation, migration, apoptosis, neurodegeneration and oncogenesis. Typically, MAPKs transduce signals from receptors to a wide variety of effector proteins, including transcription factors. Several human MAPKs, including c-Jun N-terminal kinase (JNK), extracellular signal-regulated kinases 1 and 2 (ERK1/2) and p38, are involved in hundreds of documented signalling pathways in all organs, tissues, and cell types. JNK, ERK1/2 and p38 are activated through phosphorylation at regulatory tyrosine and threonine residues in the activation loop by upstream MAPK kinases (MEKs) and dephosphorylated and inactivated by MAPK phosphatases (MKPs). MAPKs are key players in the regulation of inflammation. In response to a wide variety of chemical and biological agents, such as reactive oxygen species (ROS), they regulate the production of ROS and proinflammatory cytokines, including interferon-gamma (IFN $\gamma$ ), interleukin- $1 \beta$, interleukin-6 (IL-6) and tumour necrosis factor- $\alpha(\mathrm{TNF} \alpha)[4,5]$.

Angiotensin-converting enzyme 2 (ACE2) is a potent inhibitor of MAPK signalling and thus efficiently prevents both activation of MAPKs and pneumonia caused by exposure to cigarette smoke, particulate matter 2.5 (PM2.5), lipopolysaccharides (LPS) and bleomycin [6, 7]. However, disruption of ACE2 function occurs during severe acute respiratory syndrome coronaviruses 1 and 2 (SARS-CoV and SARS-CoV-2, respectively) infection, when the ACE2 receptor is bound by viral spike protein leading to MAPK activation and the production of proinflammatory cytokines and causing pneumonia or even acute respiratory distress syndrome (ARDS) [8]. Therefore, the inhibition of active MAPKs could be a strategy to prevent acute severe coronavirus disease 2019 (COVID-19).

Since inactive plant MAPKs are activated upon $\mathrm{CO}_{2}$ binding, and active MAPKs are inactivated by $\mathrm{CO}_{2}$ [9], we investigated MAPK susceptibility to $\mathrm{CO}_{2}$ in vitro and in human cells.

\section{Materials and methods}

\section{Cell culture}

The stable human umbilical vein endothelial cell (EC) line EA.hy926 (ATCC CRL-2922, RRID:CVCL_3901, ATCC, Manassas, Virginia, US) and normal human bronchial epithelial cell line BEAS-2B (ATCC CRL-9609, RRID:CVCL_UR57) were cultured in Dulbecco's modified Eagle's medium (DMEM; with 5.55 or $25 \mathrm{mM}$ glucose) or DMEM/nutrient mixture F-12 (DMEM/F12; $17.5 \mathrm{mM}$ glucose), respectively, supplemented with heat-inactivated $10 \%$ foetal bovine serum (FBS), 1\% L-glutamine and $1 \%$ penicillin/streptomycin. The EA.hy926 cell culture medium was additionally supplemented with $2 \%$ hypoxanthine-aminopterin-thymidine (HAT). The cells were cultured in a humidified $5 \% \mathrm{CO}_{2}$ atmosphere at $37^{\circ} \mathrm{C}$ until they reached approximately $80 \%$ (BEAS-2B) or $95 \%$ (EA.hy926) confluence, and the medium was exchanged every 3 days. The cells were treated with the indicated concentrations of the receptor-binding domain (RBD) of SARS-CoV-2 spike protein 
(ABclonal, RP01278) and dexamethasone (dex) (SigmaAldrich, D1756), $1 \mathrm{mg} / \mathrm{ml}$ LPS (Cell Signaling Technology, \#14011), $10 \mathrm{ng} / \mathrm{ml}$ TNF $\alpha$ (Cell Signaling Technology, \#8902SC), $7.5 \mathrm{ng} / \mathrm{ml} \mathrm{IFN \gamma} \mathrm{(Merck,} \mathrm{IF002),} 5$ mM (E/Z)-BCI hydrochloride (BCI; Sigma-Aldrich, B4313), $2.5 \mu \mathrm{M}$ U0126 (Adooq Bioscience, A10957), 25 MM PD98059 (Adooq Bioscience, A10705) and phosphate-buffered saline (PBS) and/or dimethyl sulfoxide (DMSO) as controls 2 days after the cells had reached confluence and $12 \mathrm{~h}$ (for treatments shorter than $1 \mathrm{~h}$ ) or $2 \mathrm{~h}$ (for longer treatments) after medium exchange.

Primary cells, i.e. human umbilical vein endothelial cells (HUVECs, Lonza, C2519A) and human pulmonary microvascular endothelial cells (HPMECs, ScienCell, 3000), were cultured in endothelial cell growth medium-2 (EGM-2, Lonza, CC-3162) or microvascular endothelial cell growth medium-2 (EGM-2 MV, Lonza, CC-3202), respectively, according to the manufacturers' protocols. The HPMECs were grown on vessels coated with $2 \mu \mathrm{g} / \mathrm{cm}^{2}$ bovine plasma fibronectin (ScienCell, 8248). All experiments were conducted at passages 2-3 using confluent HUVECs and HPMECs at 70-80\% confluency after exchange of EGM-2 or EGM-2 MV with heparin- and hydrocortisone-free media. A number of administered spike-pseudotyped lentivirus particles corresponded to the doubled tissue culture infectious dose $50 \%\left(\mathrm{TCID}_{50}\right)$ in a standard assay $\left(2\right.$ days at $37^{\circ} \mathrm{C}$ with $5 \% \mathrm{CO}_{2}$ ) on HEK293 cells expressing ACE2.

The following reagents were deposited by the Centers for Disease Control and Prevention and obtained through BEI Resources, NIAID, NIH: SARS-Related Coronavirus 2, Isolate USA-WA1/2020, heat inactivated (NR52286) and SARS-Related Coronavirus 2, Isolate USA/ CA_CDC_5574/2020, heat inactivated, NR-55245. The following reagents were obtained through BEI Resources, NIAID, NIH: SARS-Related Coronavirus 2, Wuhan-Hu-1 spike-pseudotyped lentivirus, Luc2/ZsGreen, NR-53818, SARS-Related Coronavirus 2, Wuhan-Hu-1 spike D614Gpseudotyped lentivirus, Luc2/ZsGreen, NR-53819, and Spike glycoprotein (stabilised) from SARS-Related Coronavirus 2, B.1.1.7 lineage with C-terminal histidine and Avi tags, recombinant from HEK293 cells, NR-55311.

\section{General considerations regarding $\mathrm{CO}_{2}$ treatment}

The $\mathrm{CO}_{2}$ concentrations $(6.5-10 \%)$ used for ERK1/2 regulation are in the physiological range based on the following assumptions. (i) In central venous blood, the normal partial pressure of $\mathrm{CO}_{2}\left(\mathrm{pCO}_{2}\right), 45 \mathrm{~mm} \mathrm{Hg}$ [10], is equal to both $6 \mathrm{kPa}$ and $\mathrm{CO}_{2}$ dissolved from an atmosphere containing $6 \% \mathrm{CO}_{2}$. (ii) Typical therapeutic breathing of $5 \% \mathrm{CO}_{2}$ (see "Discussion") leads to an increase in the blood $\mathrm{pCO}_{2}$ by $10-13 \mathrm{~mm} \mathrm{Hg}$. After summing $(58 \mathrm{~mm} \mathrm{Hg})$, the $\mathrm{pCO}_{2}$ corresponds to dissolved $\mathrm{CO}_{2}$ from air containing $8 \% \mathrm{CO}_{2}$. (iii) The intracellular $\mathrm{pCO}_{2}$ is higher than that in blood. $\mathrm{CO}_{2} /$ $\mathrm{HCO}_{3}{ }^{-}$calculations were made using Aqion software (www. aqion.de).

\section{Immunoblotting}

Immunoblotting was carried out as described previously [11]. The following antibodies were purchased from Abcam: anti-GAPDH (1:2500, $37 \mathrm{kDa}, \mathrm{AB} 9485$, RRID:AB_307275), anti-IL-6 (1:2000, 17 and $50 \mathrm{kDa}$, ab9324, RRID:AB_307175), and anti-ICAM-1 (1:4000, $90 \mathrm{kDa}$, AB53013, RRID:AB_870702). Anti-ACE2 (1:1000, $125 \mathrm{kDa}$, MA532307, RRID:AB_2809589) and anti-HIF-1 $\alpha$ (1:1000, $130 \mathrm{kDa}$, PA5-85,494, RRID:AB_2792634) antibodies were obtained from Thermo Scientific. The following antibodies were purchased from Cell Signaling Technology: anti-ERK1/2 (1:1000, 42, $44 \mathrm{kDa}$ \#4695, RRID:AB_390779), anti-phospho-ERK1/2 (Thr202/ Tyr204), (1:1000, 42, $44 \mathrm{kDa}$, \# 9101, RRID:AB_331646), anti-MSK1 (1:1000, $95 \mathrm{kDa}$, \#3489, RRID:AB_2285349), anti-phospho-MSK1 (Thr581) (1:1000, $95 \mathrm{kDa}$, \#9595, RRID:AB_2181783), anti-p38 (1:1000, $43 \mathrm{kDa}$ \#9212, RRID:AB_330713), anti-phospho-p38 (Thr180/Tyr182) (1:1000, $43 \mathrm{kDa}$, \#4511, RRID:AB_2139682), anti-phospho-JNK (Thr183/Tyr185) (1:1000, 46, 54 kDa, \#4668, RRID:AB_823588), anti-JNK (1:1000, 46, 64 kDa, \#9252, RRID:AB_2250373), anti-phospho-NFkB p65 (Ser536) (1:1000, $70 \mathrm{kDa}, \# 3033$, RRID:AB_331284), and anti-NFKB p65. (1:1000, $70 \mathrm{kDa}$, \#6956, RRID:AB_10828935). The following antibody were obtained from ABclonal (Woburn, MA): anti-phospho-NFkB p65 (S276) (1:1000, $70 \mathrm{kDa}$, AP0123, RRID:AB_2771505). An anti-phospho-MBP antibody (1:200, $18 \mathrm{kDa}, 13-104)$ was purchased from Merck.

\section{Immunoprecipitation}

ECs were rinsed twice with ice-cold PBS, scraped off and centrifuged $\left(700 \times g, 1 \mathrm{~min}, 4{ }^{\circ} \mathrm{C}\right)$. The pellet containing $2 \times 10^{8}$ ECs was lysed ( $5 \mathrm{~min}$ on ice) in $2 \mathrm{ml}$ of buffer containing $100 \mathrm{mM}$ Tris- $\mathrm{HCl} \mathrm{pH} \mathrm{7.5,} 600 \mathrm{mM} \mathrm{NaCl}, 75 \mathrm{mM}$ NaF, 6 mM EDTA, 0.1\% NP40, 4 mM DTT, 1 mM PMSF and protease (Roche) and phosphatase (Thermo Scientific) inhibitor cocktails. Then, $5 \mathrm{ml}$ of ice-cold deionised water was added, and the lysates were centrifuged $(10,000 \times g$, $\left.10 \mathrm{~min}, 4^{\circ} \mathrm{C}\right)$. The supernatants were incubated for $1 \mathrm{~h}$ at $4{ }^{\circ} \mathrm{C}$ with $250 \mu$ l of Dynabeads ${ }^{\circledR}$ Protein G (Life Technologies, Oslo, Norway) for preclearing. Then, the Dynabeads ${ }^{\circledR}$ Protein $\mathrm{G}$ was replaced with $40 \mathrm{ml}$ of anti-ERK1/2 antibody coupled with Dynabeads. The suspensions were incubated overnight at $4{ }^{\circ} \mathrm{C}$ with slow agitation and then washed six times with PBST and two times with deionised water. 


\section{ERK1/2 dephosphorylation}

Immunoprecipitated ERK1/2 were dephosphorylated at $37{ }^{\circ} \mathrm{C}$ for $1 \mathrm{~h}$ in a reaction mixture containing $10 \mathrm{mM}$ Tris- $\mathrm{HCl} \mathrm{pH}$ 8.0, $5 \mathrm{mM} \mathrm{MgCl}_{2}, 100 \mathrm{mM} \mathrm{KCl}, 0.02 \%$ Triton $\mathrm{X}-100$ and $600 \mathrm{U}$ of alkaline phosphatase (FastAP, Thermo Scientific). After FastAP inactivation with $50 \mathrm{mM}$ EDTA followed by six washes with PBST and two washes with deionised water, ERK1/2 were used in in vitro phosphorylation reactions.

\section{In vitro kinase activity assay}

Immunoprecipitated ERK1/2 were incubated (20 min, $30{ }^{\circ} \mathrm{C}$ ) with $5 \mu \mathrm{g}$ of dephosphorylated MBP (Millipore, Temecula, CA, USA) in buffer containing $100 \mathrm{mM}$ MOPS (pH 6.7 or 7.4), $0.5 \mathrm{mM}$ EGTA, $1 \mathrm{mM}$ DTT, $20 \mathrm{mM} \mathrm{MgCl}_{2}$, $200 \mu \mathrm{M}$ ATP and EDTA-Free Protease and Phosphatase Inhibitor Tablets (Thermo Scientific, Rockford, IL) with the indicated concentration of freshly dissolved $\mathrm{NaHCO}_{3}$. Then, the proteins were denatured in SDS-PAGE sample loading buffer and subjected to immunoblotting with an antiphospho-MBP antibody.

\section{Quantitative measurement of IL-6 levels}

Measurement of the level of IL-6 in cell culture supernatants was carried out using an enzyme-linked immunosorbent assay (ELISA) kit (Cat \# 430504, BioLegend, San Diego, CA) according to the manufacturer's instructions.

\section{RNA extraction and RT-qPCR}

RNA extraction with TRI reagent (Sigma-Aldrich) and reverse transcription using a RevertAid H Minus First-Strand cDNA Synthesis Kit (Thermo Fisher Scientific, K1631) were conducted according to the manufacturers' protocols and described previous particulars [12]. PowerUp ${ }^{\mathrm{TM}} \mathrm{SYBR}^{\circledR}$ Green Master Mix (Thermo Fisher Scientific, A25742) and StepOnePlus Real-Time PCR System (Thermo Fisher Scientific) were used to perform qPCR with primers specific to ACE2 (ACCAGTGGATGAAAAAGTGGTG and AGAAAC ATGGAACAGAGATGCG), GAPDH (GTCTCCTCTGAC TTCAACAGCG and ACCACCCTGTTGCTGTAGCCAA) and $A C T B$ (CACCATTGGCAATGAGCGGTTC and AGG TCTTTGCGGATGTCCACGT). The $2^{-\Delta \Delta C T}$ method [13] was applied to calculate the relative level of $A C E 2 \mathrm{mRNA}$.

\section{Statistical analysis}

ImageJ software was employed for densitometric analysis of the immunoblotting bands. The expression levels of total kinases and GAPDH and Ponceau S staining were used for data normalisation. For relative quantification, the value of the mock treatment group was considered 1 . The means \pm standard deviations (SD) are shown. The significance of differences was calculated using a two-tailed $T$-test (Fig. S3a) or one-way or factorial ANOVA followed by Tukey's post hoc test (other Figs). The means \pm SDs of three independent experiments are presented. $*, * *$ and $* * *$ indicate significant differences in ERK $1 / 2$ activity $(p<0.05$, $p<0.01$ and $p<0.001$, respectively).

\section{Results}

We focused on ECs (cell line EA.hy926) to test hypotheses regarding the potential role of $\mathrm{CO}_{2}$ in regulating ERK1/2 activity, because ECs in the lungs, heart and brain are strongly affected in COVID-19, and COVID-19 is considered a form of inflammatory endothelialitis $[14,15]$.

\section{ERK1/2 are activated by $\mathrm{CO}_{2}$ in vitro and in human cells}

First, we tested whether ERK1/2, the most closely related human MAPKs to plant MAPKs, are directly regulated by $\mathrm{CO}_{2}$ (Fig. 1a). Inactive ERK1/2 immunoprecipitated from ECs were activated by $\mathrm{HCO}_{3}{ }^{-}$in vitro in a dose-dependent manner up to $25 \mathrm{mM} \mathrm{HCO}_{3}{ }^{-}$at $\mathrm{pH} 6.7\left(32.4 \% \mathrm{CO}_{2}\right.$ and $67.6 \% \mathrm{HCO}_{3}{ }^{-}$in the reaction mixture), whereas activation was weak at pH $7.4\left(8.7 \% \mathrm{CO}_{2}\right.$ and $\left.91.2 \% \mathrm{HCO}_{3}{ }^{-}\right)$. This result indicates that dissolved $\mathrm{CO}_{2}$, but not $\mathrm{HCO}_{3}{ }^{-}$, activates ERK1/2. The decrease in ERK1/2 activity in the presence of $30 \mathrm{mM} \mathrm{HCO}_{3}{ }^{-}$, which is close to the concentration in plasma, suggests that ERK1/2 can be activated by both increasing and decreasing the cellular $\mathrm{CO}_{2}$ concentration. Then, we found that transient activation of ERK1/2 in ECs occurred at all tested $\mathrm{CO}_{2}$ concentrations $(6.5-15 \%$; Fig. 1b, $\mathrm{S} 1 \mathrm{a})$. It was clear that the higher the $\mathrm{CO}_{2}$ concentration was, the earlier and shorter the maximal ERK1/2 activation. Since $\mathrm{CO}_{2}$ causes acidification of solutions, we showed that the activation of ERK1/2 in ECs was also induced by both $\mathrm{NaHCO}_{3}$ (which increases the $\mathrm{pH}$ ) and neutralised ( $\mathrm{pH}$ 7.4) $\mathrm{CO}_{2}$ (Fig. 1c). Thus, ERK1/2 activation was triggered by $\mathrm{CO}_{2}$, not at a certain $\mathrm{pH}$. Lower $\mathrm{CO}_{2}$-induced ERK1/2 activation was found at a higher $\mathrm{pH}$ (Fig. 1d), which further confirms the free $\mathrm{CO}_{2}$ is better able to activate MAPKs than $\mathrm{HCO}_{3}{ }^{-}$, as found in vitro and in plants [9]. To define whether $\mathrm{CO}_{2}$-dependent regulation of ERK1/2 activity is a universal process that takes place in different cell types, we confirmed that $10 \% \mathrm{CO}_{2}$ induced transient ERK1/2 activation in BEAS2B cells (Fig. S1b). To verify that $\mathrm{CO}_{2}$ directly activated ERK1/2 in ECs, we showed that ERK1/2 were still activated by $\mathrm{CO}_{2}$ in the presence of MEK1/2 inhibitors (U0126 and 

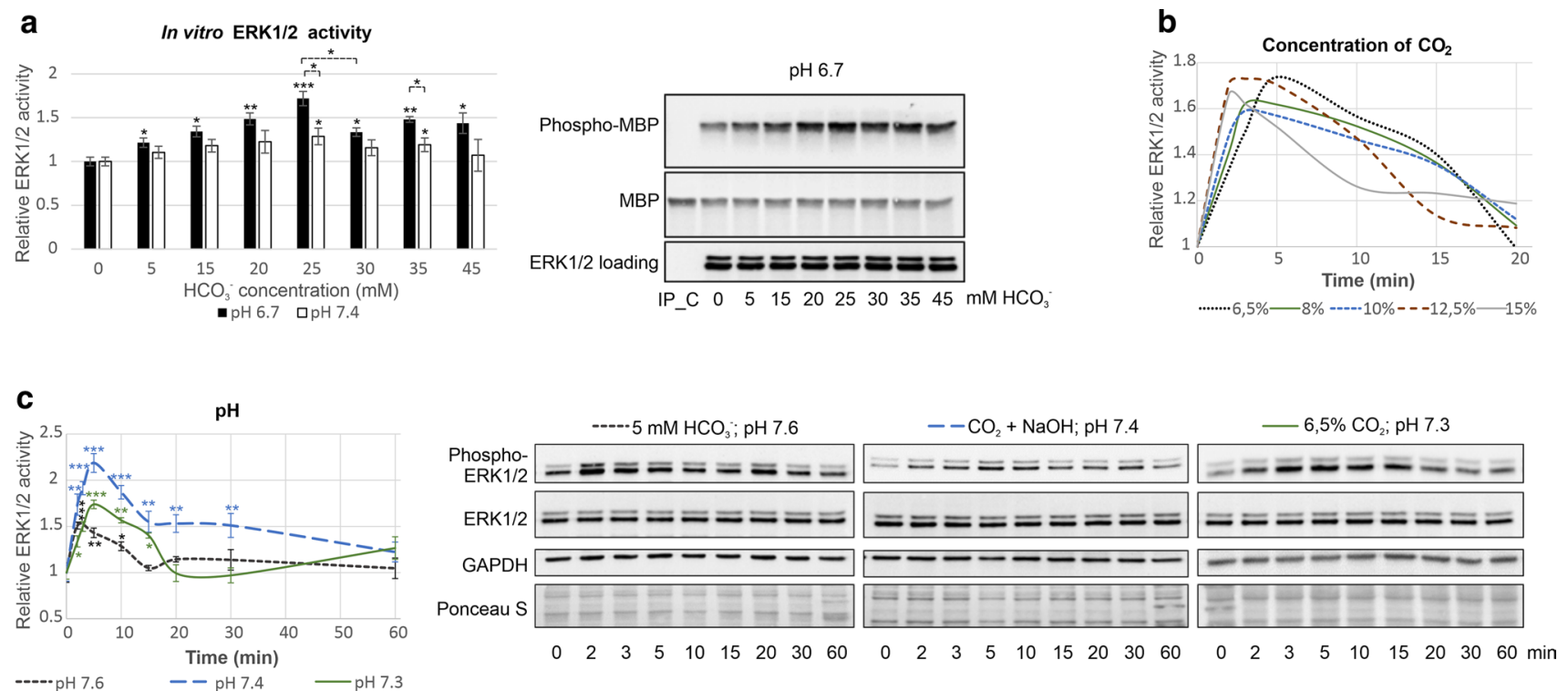

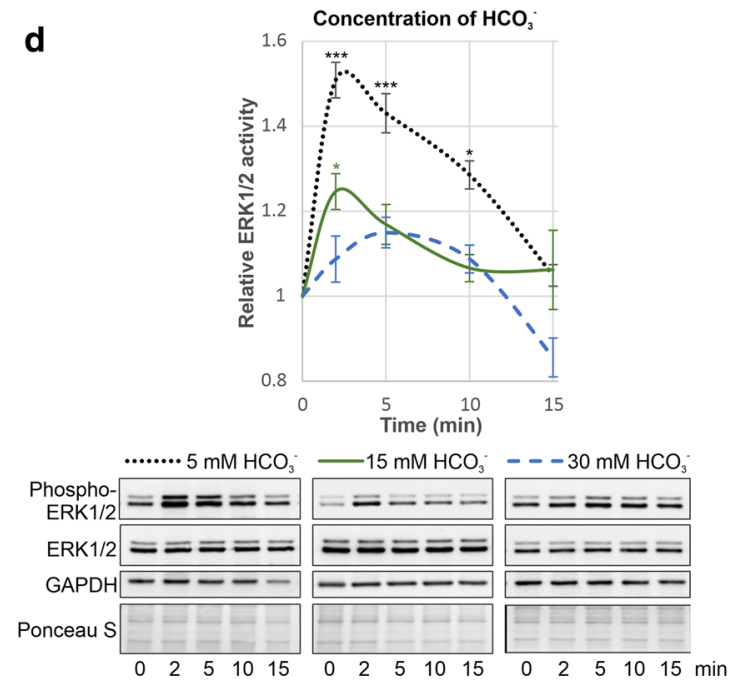

Fig. 1 MAPKs are regulated by $\mathrm{CO}_{2}$. a $\mathrm{CO}_{2}$ directly regulates ERK1/2 activity in vitro. ERK1/2 immunoprecipitated from ECs was dephosphorylated and subjected to an in vitro kinase activity assay in the presence of the indicated concentration of $\mathrm{HCO}_{3}{ }^{-}$. Phosphorylation of MBP, which was used as an ERK1/2 substrate for in vitro phosphorylation reactions, was measured by immunoblotting with an anti-phospho-MBP antibody. The levels of ERK1/2 were determined using immunoblotting with an anti-ERK1/2 antibody, and MBP was visualised by Ponceau S staining. An immunoprecipitation control (IP_C), i.e. Dynabeads Protein G incubated with cell lysates without the anti-ERK1/2 antibody, was used to show the specificity of the assay. $\mathbf{b}$ In ECs, ERK1/2 were transiently activated by $\mathrm{CO}_{2}$ at a wide range of concentrations. Graphs for the individual $\mathrm{CO}_{2}$ concentrations with bars representing the SD are presented in Fig. S1a. c $\mathrm{CO}_{2}$ promotes ERK1/2 activation regardless of $\mathrm{pH}$. Time courses
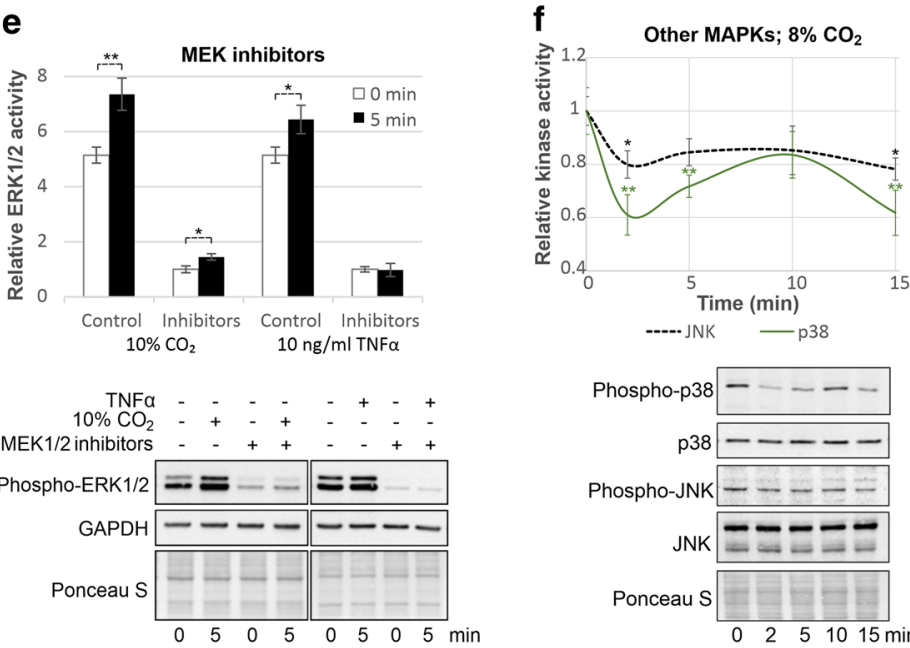

of ERK1/2 activation at $\mathrm{pH} 7.4\left(\mathrm{CO}_{2}\right.$ neutralised by $\left.\mathrm{NaOH}\right)$ and at a lower $\left(6.5 \% \mathrm{CO}_{2}\right)$ or higher $\left(\mathrm{NaHCO}_{3}\right) \mathrm{pH}$ are shown. d Time courses of $\mathrm{HCO}_{3}{ }^{-}$-induced ERK1/2 activation in ECs. e ERK1/2 were activated by $\mathrm{CO}_{2}$ independently of upstream MEK1/2 in ECs, as MEK1/2 inhibitors (2.5 $\mu \mathrm{M}$ U0126 and $25 \mu \mathrm{M}$ PD98059) did not abolish the $\mathrm{CO}_{2}$-induced ERK1/2 activation but did prevent ERK1/2 activation by $10 \mathrm{ng} / \mathrm{ml} \mathrm{TNF} \alpha$. In b-e, ERK1/2 activity was measured by immunoblotting with an anti-phospho-ERK1/2 antibody. Protein loading was assessed by both Ponceau S staining and immunoblotting with anti-GAPDH and anti-ERK1/2 antibodies. $\mathbf{f} \mathrm{JNK}$ and p38 were inactivated by $\mathrm{CO}_{2}$ in ECs. JNK and p38 activity was determined by immunoblotting with anti-phospho-JNK and anti-phospho-p38 antibodies, respectively. The results of three independent experiments are presented 
PD98059), while activation of ERK1/2 by TNF $\alpha$ was abolished under these conditions (Fig. 1e).

\section{$\mathrm{CO}_{2}$ inhibits active ERK1/2}

Since p38 and JNK are inactivated by $\mathrm{CO}_{2}$ (Fig. 1f) and active plant MAPKs can be inactivated by $\mathrm{HCO}_{3}{ }^{-} / \mathrm{CO}_{2}$ in vitro [9], we asked whether human ERK1/2 are subject to such unusual conditional positive or negative regulation in ECs. To this end, ECs were exposed to $100 \mu \mathrm{M} \mathrm{H}_{2} \mathrm{O}_{2}$ because unlike most factors, which transiently activate ERK1/2 (typically up to $30 \mathrm{~min}$ ), $\mathrm{H}_{2} \mathrm{O}_{2}$ at a concentration of
$100 \mu \mathrm{M}$ permanently activates ERK1/2. Activated ERK1/2 were successfully inhibited by $30 \mathrm{mM} \mathrm{HCO}_{3}{ }^{-}$over a time range of 2 to $4 \mathrm{~h}$ (Fig. S2a). More stable ERK1/2 inactivation can be achieved by repeated treatment with buffered (pH 7.4) $\mathrm{HCO}_{3}{ }^{-}$(Fig. S2b) or $\mathrm{CO}_{2}$ (Fig. S2c). Transient hypercapnia, or an increased $\mathrm{pCO}_{2}$, is a physiological condition affecting the blood vessels, and further experiments were conducted using a transient increase in the $\mathrm{CO}_{2}$ concentration to avoid the introduction of additional compounds ( $\mathrm{NaOH}, \mathrm{HEPES})$ to the cell culture medium.

Efficient inhibition of ERK1/2 below baseline levels was induced by an increase in the $\mathrm{CO}_{2}$ concentration for $11 \mathrm{~min}$

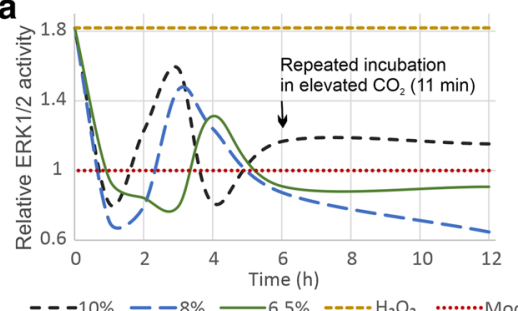

b

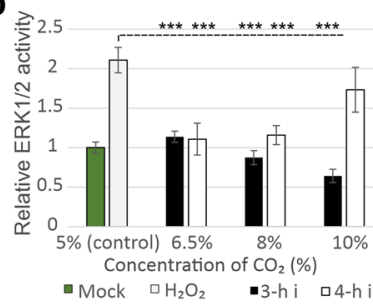

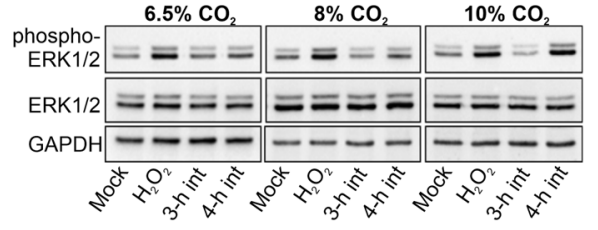

d

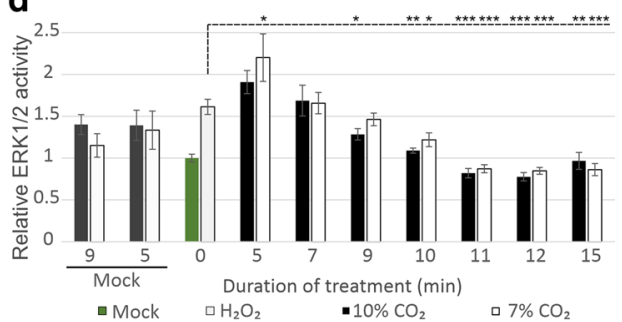
$\square \mathrm{H}_{2} \mathrm{O}_{2}$
$\mathbf{C}_{1.6}$

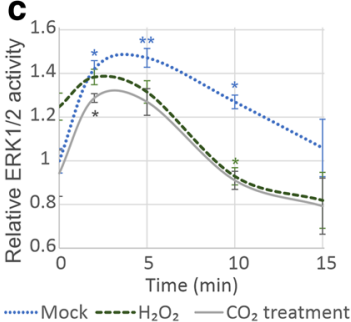

e

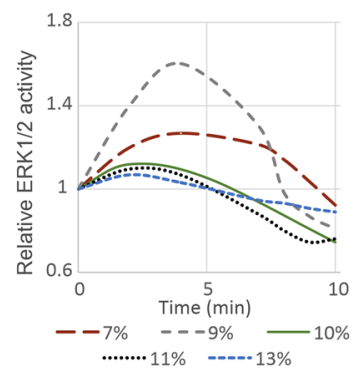

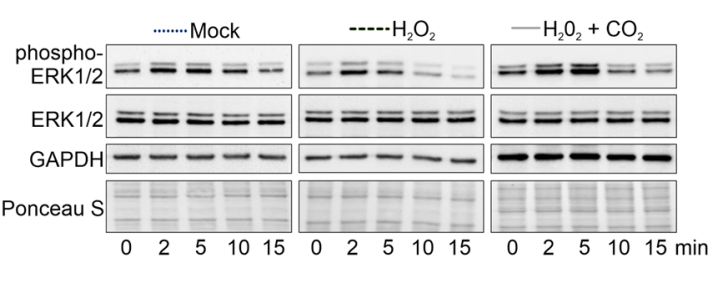

f

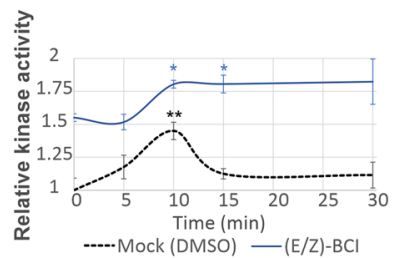

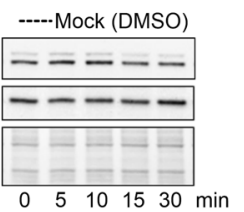

Fig. 2 Active MAPKs are inhibited by $\mathrm{CO}_{2}$. In a-e, ERK1/2 were activated by treatment of ECs with $100 \mu \mathrm{M} \mathrm{H}_{2} \mathrm{O}_{2}$ for $12 \mathrm{~h}$ before inactivation by $\mathrm{CO}_{2}$. a CO $\mathrm{CO}_{2}$ inhibited the activity of ERK1/2 preactivated by $100 \mu \mathrm{M} \mathrm{H}_{2} \mathrm{O}_{2}$. Additional incubation with elevated $\mathrm{CO}_{2}$ ( $6 \mathrm{~h}$ after the first incubation) promoted stable ERK1/2 inactivation. Graphs showing the time course of ERK1/2 activity in response to particular $\mathrm{CO}_{2}$ concentrations with bars representing the SD are depicted in Fig. S2d. b A stable decrease in ERK1/2 activity was achieved by retreatment with elevated $\mathrm{CO}_{2}$. Additional incubations were initiated at different phases of ERK1/2 re-activation in a, i.e. in the third and fourth hour. $\mathrm{c}$ ERK1/2 inactivation by $\mathrm{CO}_{2}$ was preceded by short activation. Inactivation of ERK $1 / 2$ preactivated with $100 \mu \mathrm{M} \mathrm{H}_{2} \mathrm{O}_{2}$ or additional treatment with $10 \% \mathrm{CO}_{2}(11 \mathrm{~min}$, three times at 3-h intervals) was earlier than that of control ERK1/2. d Exposure to elevated $\mathrm{CO}_{2}$ for a sufficient duration was crucial for ERK1/2 inactivation. ECs in which ERK1/2 was activated by $100 \mu \mathrm{M} \mathrm{H}_{2} \mathrm{O}_{2}$ were incubated for the indicated times in 7 or $10 \%$ $\mathrm{CO}_{2}$ (three treatments at 3-h intervals). ERK1/2 activity measured $2 \mathrm{~h}$ after the last treatment is shown. e Timing of ERK1/2 inactivation in response to different $\mathrm{CO}_{2}$ concentrations. Graphs for the individual $\mathrm{CO}_{2}$ concentrations with bars representing the SD are shown in Fig. S2e. f ERK1/2 inactivation by $\mathrm{CO}_{2}$ was MKP-1-dependent. Time course of ERK1/2 activity in ECs treated with $10 \% \mathrm{CO}_{2}$ in the presence of either DMSO or BCI, a specific MKP-1 inhibitor. In a-f, ERK1/2 activity was assessed by immunoblotting with an antiphospho-ERK1/2 antibody and normalised to protein loading, which was assessed by Ponceau S staining and immunoblotting with antiGAPDH and anti-ERK1/2 antibodies. The results are presented as the mean \pm SD of three independent experiments 
(Figs. 2a, S2d). After a strong decline, ERK1/2 activity was partially and temporarily restored starting at the 2 nd or $3 \mathrm{rd} \mathrm{h}$ depending on the $\mathrm{CO}_{2}$ concentration. The decrease in ERK1/2 activity could be prolonged by additional incubations with $\mathrm{CO}_{2}$ at an elevated concentration. Additional incubations were initiated at different phases of ERK1/2 reactivation (Fig. 2b), and the most efficient ERK1/2 inactivation was observed when incubation was performed during peak ERK1/2 activity. In contrast, statistically insignificant ERK1/2 inactivation was noticed when $\mathrm{CO}_{2}$ was applied again when ERK1/2 was mostly inactive ( 4 th $\mathrm{h}, 10 \% \mathrm{CO}_{2}$ ).

Effective inactivation of ERK1/2 was noted for different $\mathrm{CO}_{2}$ concentrations. Therefore, we looked for other factors affecting ERK1/2 activity induced by $\mathrm{CO}_{2}$. After stimulation with $\mathrm{H}_{2} \mathrm{O}_{2}$ alone or in combination with $10 \% \mathrm{CO}_{2}$ (11 min, 3 times, 3-h intervals), ERK1/2 were initially activated by $\mathrm{CO}_{2}$ before inactivation, and the time required to achieve baseline ERK1/2 activity was much shorter in $\mathrm{H}_{2} \mathrm{O}_{2}$-treated ECs than in control ECs (less than 10 and 15 min, respectively; Fig. 2c). Therefore, we asked whether the duration of incubation with elevated $\mathrm{CO}_{2}$ is essential for the effect of ERK1/2 inhibition. To this end, we analysed the inhibition of $\mathrm{H}_{2} \mathrm{O}_{2}$-induced ERK1/2 following three incubations with elevated (7 or 10\%) $\mathrm{CO}_{2}$ for different duration at 3-h intervals (Fig. 2d). We found that incubations longer than $7 \mathrm{~min}$ were required to reduce ERK1/2 activity and that incubations longer than 9 min decreased ERK1/2 activity below the baseline level. Overall, the longer the incubation periods with elevated $\mathrm{CO}_{2}$, the more effective the ERK1/2 inhibition. However, exposure to elevated $\mathrm{CO}_{2}$ for longer than $12 \mathrm{~min}$ did not enhance the inhibitory effect of $\mathrm{CO}_{2}$, and incubation for shorter than $7 \mathrm{~min}$ enhanced ERK1/2 activity. We also examined the response of ERK1/2 preactivated by $\mathrm{H}_{2} \mathrm{O}_{2}$ to different levels of $\mathrm{CO}_{2}$ (Figs. 2e, S2e). At a concentration of $7-9 \%, \mathrm{CO}_{2}$ first triggered marked ERK1/2 activation followed by inactivation after $7 \mathrm{~min}$, whereas the inactivation caused by $10-13 \% \mathrm{CO}_{2}$ occurred earlier and was preceded by only weak ERK1/2 activation.

The kinetics of $\mathrm{CO}_{2}$-induced ERK1/2 activation followed by inactivation resembles the pattern of ERK $1 / 2$ activity changes evoked by dex (Fig. S2f). Since ERK1/2 inactivation by dex depends on increased MKP-1 expression [16], we checked whether this is also the case for $\mathrm{CO}_{2}$. Indeed, ERK1/2 were not inactivated in the presence of BCI, a specific MKP-1 inhibitor (Fig. 2f).

\section{ERK1/2 contribute to the response to RBD in ECs}

In light of the current COVID-19 pandemic, we asked whether elevated $\mathrm{CO}_{2}$ could be effective in inhibiting the cytokine production caused by SARS-CoV-2 infection. It is accepted that the ACE2 receptor is expressed in ECs [14], and we showed that the expression of ACE2 was increased by RBD in EA.hy926 cells at both the protein and mRNA levels (Fig. S3a). SARS-CoV-2 is able to infect human blood vessel organoids and ECs in vitro without undergoing viral replication and induces a clear proinflammatory response [17]. Therefore, we were able to demonstrate that in ECs, ERK1/2 activity in response to $40 \mathrm{ng} / \mathrm{ml}$ RBD increased gradually up to $30 \%$ after $24 \mathrm{~h}$ (Fig. 3a, Fig. S3b), according to data from epithelial cells $[18,19]$.

As diabetes mellitus is one of the most significant risk factors for severe COVID-19, we compared ERK1/2 activity in response to RBD in ECs exposed to 5.55 and $25 \mathrm{mM}$ glucose (Fig. S3c). Fifteen hours after RBD application, ERK1/2 were activated in a concentration-dependent manner up to $400 \mathrm{ng} / \mathrm{ml} \mathrm{RBD}$, and ERK1/2 activation was higher in ECs exposed to $25 \mathrm{mM}$ glucose than to those exposed to $5.55 \mathrm{mM}$ glucose. This is consistent with the glucose-mediated induction of ACE2 expression, SARS-CoV-2 load, and cytokine and ROS production [20, 21]. Therefore, all further data were obtained from ECs cultured in $25 \mathrm{mM}$ glucose.

\section{RBD-activated ERK1/2 are inhibited by $\mathrm{CO}_{2}$}

Although activation of ERK1/2 in response to RBD was weaker than that in response to $\mathrm{H}_{2} \mathrm{O}_{2}$, RBD-induced ERK1/2 activation was less effectively inhibited, and exposure to $10 \%$ $\mathrm{CO}_{2}$ three times at an interval of $3 \mathrm{~h}$ was necessary to retain baseline ERK1/2 activity (Fig. 3b). To directly compare the therapeutic effect of $\mathrm{CO}_{2}$ with that of anti-inflammatory drugs that inhibit ERK1/2 activity, we applied 10, 50 or $200 \mathrm{nM}$ dex and 10 or $50 \mu \mathrm{M}$ aspirin. Exposure to $10 \% \mathrm{CO}_{2}$ five times for 12 min more efficiently inhibited ERK1/2 activity than aspirin and 10 or $50 \mathrm{nM}$ dex (Fig. 3c). Importantly, $\mathrm{CO}_{2}$ acted synergistically with dex and aspirin, except dex was used at a concentration of $200 \mathrm{nM}$. Interestingly, the aspirin-induced changes in ERK1/2 activity over time were distinct from those of dex and $\mathrm{CO}_{2} ; \mathrm{ERK} 1 / 2$ were inactivated beginning from the 5th min but did not exhibit initial strong activation (Fig. S3d).

Then, we aimed to show the versatility of $\mathrm{CO}_{2}$-induced inactivation of ERK1/2. In contrast to studies showing that ACE2 is not expressed at the mRNA level in BEAS-2B cells [22], we confirmed the results of other groups [19] demonstrating the presence of ACE2 protein and weak transient activation of ERK1/2 by RBD in BEAS-2B cells (Fig. S4a-b). However, RBD-induced ERK1/2 activation was suppressed after $3 \mathrm{~h}$, consistent with the known decrease in ACE2 expression induced by spike in epithelial cells [8]. Therefore, we measured ERK1/2 activity after induction by RBD in combination with IFN $\gamma$ and TNF $\alpha$ since IFN $\gamma$ and $\mathrm{TNF} \alpha$ are responsible for acute SARS-CoV-2 infection along with IL-6 [23] and activate ERK1/2 in many cell types to promote IL-6 production. IFN $\gamma$ was found to play a key role in potent and long-term ERK1/2 activation in BEAS2B cells (Fig. S4a, b). Conversely, ACE2 expression was decreased at the same time (Fig. S4a), supporting its role as an ERK1/2 inhibitor [6, 7]. 
a
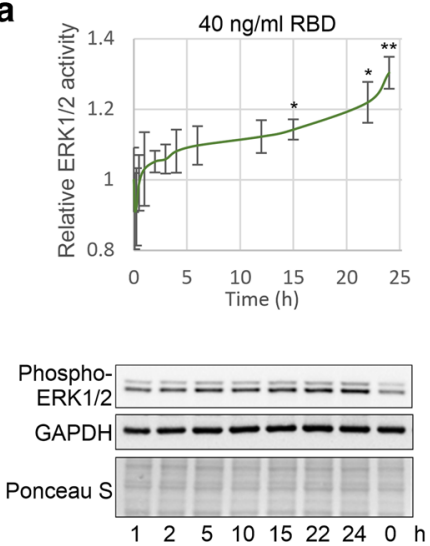

d
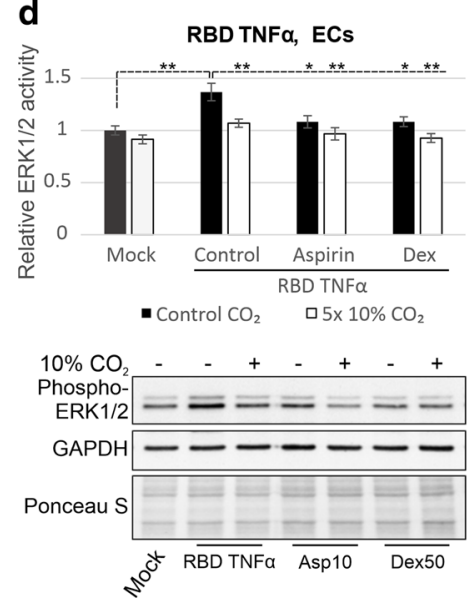

b
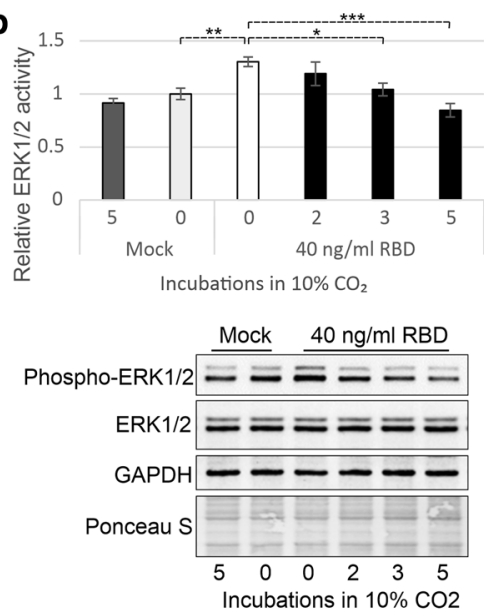

e
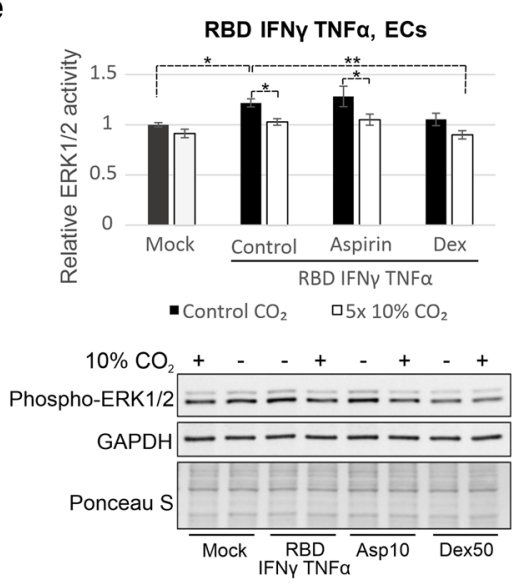

C
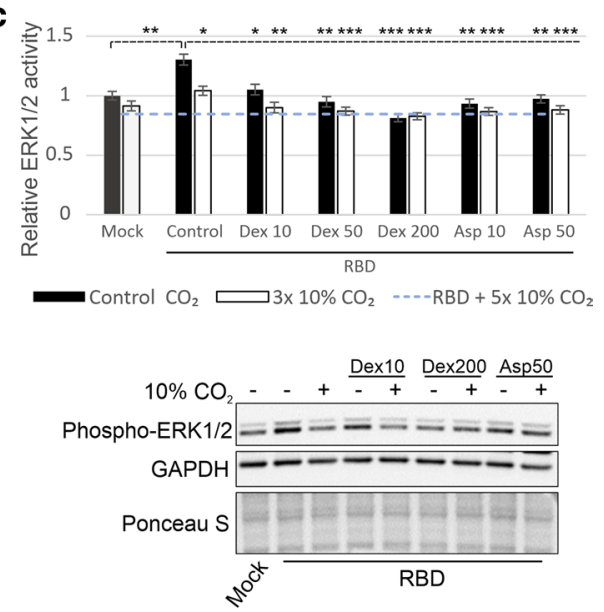

f

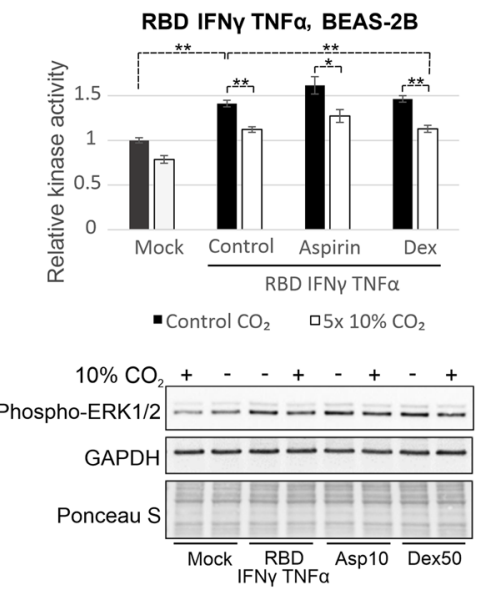

Fig. 3 RBD-induced ERK1/2 activation can be inhibited by $\mathrm{CO}_{2}$. a Time course of ERK1/2 activation by $40 \mathrm{ng} / \mathrm{ml}$ RBD in ECs. b $\mathrm{CO}_{2}$ decreased ERK1/2 activity enhanced by $40 \mathrm{ng} / \mathrm{ml} \mathrm{RBD}$ in ECs. The indicated number of treatments with $10 \% \mathrm{CO}_{2}(11 \mathrm{~min}$, a 3-h interval for " $3 \times \mathrm{CO}_{2}$ " and " $5 \times \mathrm{CO}_{2}$ " and a 6 -h interval for " $2 \times \mathrm{CO}_{2}$ ") was applied $2 \mathrm{~h}$ before collection of ECs and $22 \mathrm{~h}$ after RBD administration. c Comparison of the efficiency of ERK1/2 activity inhibition by $\operatorname{dex}(10,50$ or $200 \mathrm{nM}), 10$ or $50 \mu \mathrm{M}$ aspirin (asp) and $10 \% \mathrm{CO}_{2}$. ECs were incubated with $40 \mathrm{ng} / \mathrm{ml} \mathrm{RBD}$ for $16 \mathrm{~h}$. Then, dex and aspirin were applied directly after the first treatment with $10 \% \mathrm{CO}_{2}(11 \mathrm{~min})$

Unlike in BEAS-2B cells, TNF $\alpha$ enhanced RBDinduced ERK1/2 activation in ECs (Fig. S4c-e). Therefore, we applied RBD in together with TNF $\alpha$ or RBD together with TNF $\alpha$ and IFN $\gamma$ to induce ERK1/2 activity in ECs and BEAS-2B cells (Fig. 3d-f). Following five 12-min incubations in $10 \% \mathrm{CO}_{2}$, ERK1/2 activity was effectively blocked under these conditions in both cell lines (Fig. 3d-f), while aspirin failed to inhibit ERK1/2 activity in the presence of IFN $\gamma$ in ECs (Fig. 3e). Neither aspirin nor dex was able to block the activity of ERK1/2 in BEAS-2B cells (Fig. 3f). Importantly, $\mathrm{CO}_{2}$ enhanced the decline in ERK1/2 activity in the presence of dex and aspirin in all tested combinations, both in BEAS-2B cells and ECs (Fig. 3d-f).
$8 \mathrm{~h}$ before collection of ECs. d-f Efficacy of ERK1/2 inhibition by $10 \% \mathrm{CO}_{2}$ (5 treatments, $12 \mathrm{~min}$, 3-h interval), $10 \mu \mathrm{M}$ aspirin and $50 \mathrm{nM}$ dex. ECs (d-e) or BEAS-2B cells (f) were treated with $40 \mathrm{ng} /$ $\mathrm{ml} \mathrm{RBD}, 10 \mathrm{ng} / \mathrm{ml} \mathrm{TNF} \alpha$ and/or $7.5 \mathrm{ng} / \mathrm{ml} \mathrm{IFN} \gamma$ as indicated for $10 \mathrm{~h}$. Then, specified treatments were applied, and the cells were collected $14 \mathrm{~h}$ later. ERK1/2 activity was determined by immunoblotting with an anti-phospho-ERK1/2 antibody, and protein loading was assessed by Ponceau S staining and immunoblotting with anti-GAPDH and anti-ERK1/2 antibodies. The means \pm SDs of three independent experiments are presented

Notably, aspirin is known to induce aspirin-exacerbated respiratory disease (AERD), in which IFN $\gamma$ plays a crucial role [24]. Moreover, aspirin has also been reported to induce ERK1/2 activity [25]. The inability of dex to efficiently inhibit ERK1/2 (Fig. 3f) may result from the synergistic induction of Toll-like receptor 2 (TLR2; an indirect activator of ERK1/2) by dex, TNF $\alpha$, and IFN $\gamma$ in human respiratory epithelial cells, including BEAS-2B cells [26]. In addition, dex is only effective in cells, tissues and organs with active glucocorticoid receptors and signalling machineries and ERK1/2 activity plays a role in the development of corticosteroid resistance [27]. 
Next, we traced MAPK-dependent proteins that lead to proinflammatory responses. We showed that the expression of hypoxia-inducible factor 1 alpha (HIF-1 $\alpha$ ) and intercellular adhesion molecule 1 (ICAM-1) and phosphorylation of NFKB p65 and mitogen- and stress-activated protein kinase 1 (MSK1) were induced by $\mathrm{H}_{2} \mathrm{O}_{2}$ (Fig. 4a) or RBD alone (Fig. 4b) or RBD together with TNF $\alpha$ and IFN $\gamma$ (Fig. 4c) and could be decreased by $\mathrm{CO}_{2}$ in ECs. Since tocilizumab, an antibody against the IL- 6 receptor, is one of the most effective drugs for patients with severe COVID-19, we also demonstrated that the levels of both secreted and dimeric intracellular IL-6 were increased in response to both RBD and $\mathrm{H}_{2} \mathrm{O}_{2}$ and decreased by $\mathrm{CO}_{2}$ (Fig. $4 \mathrm{~d}-\mathrm{f}$ ).

To confirm the impairment of SARS-CoV-2-induced inflammation by $\mathrm{CO}_{2}$ in a more natural context, we employed primary ECs from the umbilical vein and from the pulmonary microvasculature, trimeric spike glycoprotein, spikepseudotyped lentivirus and heat-inactivated SARS-CoV-2. At a low glucose concentration $(5.55 \mathrm{mM})$, ERK1/2 activation by spike, spike-pseudotyped lentivirus or heat-inactivated SARS-CoV-2 was clearly stronger in HUVECs (Fig. 5a-d) than RBD-induced ERK1/2 activation in the EA.hy926 cell line (Fig. S3c). However, the change in ERK1/2 activity in HPMECs exposed to spike, spike-pseudotyped lentivirus or heat-inactivated SARS-CoV-2 (Fig. 5e-g) did not reach statistical significance similar to RBD-induced activation of
ERK1/2 in EA.hy926 cells under low glucose conditions. The lower activation of ERK1/2 in HPMECs compared to HUVECs may result from conducting experiments on dividing HPMECs (with lower cell density). This approach was necessary to maintain the purity of the culture because the microvasculature EC preparations are usually contaminated with other cell types and the amount of contaminants increases with the duration of the culture. In addition, HPMECs were grown on plasma fibronectin-coated vessels, and plasma fibronectin is known to modulate a number of cellular responses [28]. Then, we evaluated the activation of ERK1/2 in HPMECs in the presence of IFN $\gamma$. Whereas IFN $\gamma$ alone did not activate ERK1/2, spike with IFN $\gamma$ (Fig. 5h) or heat-inactivated SARS-CoV-2 accompanied by IFN $\gamma$ (Fig. 5i) efficiently activated ERK1/2 in $5.55 \mathrm{mM}$ glucose. A less pronounced effect was induced by spike-pseudotyped lentivirus in the presence of IFN $\gamma$ (Fig. 5j). SARS-CoV-2-derivative IFN $\gamma$ synergism was not limited to HPMECs, as spike-induced ERK1/2 activation in HUVECs was enhanced (1.74-fold) on the addition of IFN $\gamma$. (Fig. 5k).

Primary ECs are very responsive to treatment with $\mathrm{CO}_{2}$. Only one treatment with $\mathrm{CO}_{2}(8.7 \%, 12 \mathrm{~min})$ efficiently inhibited not only ERK1/2 activity but also the increase in IL-6, ICAM- 1 and HIF- $1 \alpha$ expression in primary ECs (Fig. 5b-k). IFN $\gamma$ stimulated an ERK1/2-independent increase in the IL-6 expression level in HPMECs. Thus, $\mathrm{CO}_{2}$ repressed IL-6 expression co-induced by IFN $\gamma$ and
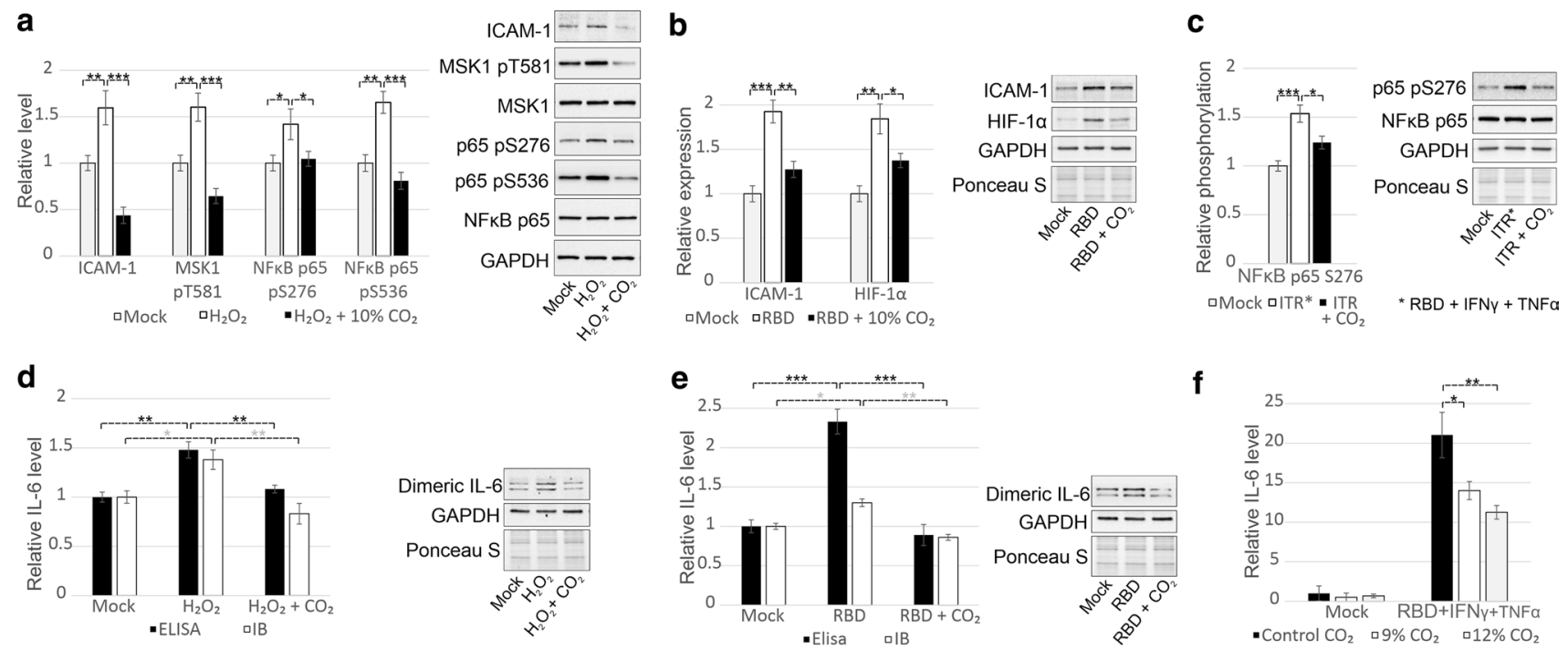

Fig. 4 ERK1/2-dependent downstream signalling and cellular responses are regulated by $\mathrm{CO}_{2}$ in ECs. a Increased expression of ICAM-1 and phosphorylation of MSK1 at T581 and NFkB p65 at S276 and $\mathrm{S} 536$ in response to $100 \mu \mathrm{M} \mathrm{H}_{2} \mathrm{O}_{2}$ were abrogated by treatment with $10 \% \mathrm{CO}_{2}$ (11 min, 4 times, 3-h interval). b The expression of HIF- $1 \alpha$ and ICAM-1 were induced by $40 \mathrm{ng} / \mathrm{ml} \mathrm{RBD}$ and could be decreased by $10 \% \mathrm{CO}_{2}$ in ECs (4 incubations, $11 \mathrm{~min}, 3$-h interval). $\mathbf{c}$ The phosphorylation of NFkB p65 at S276 was increased in response to RBD, TNF $\alpha$ and IFN $\gamma$ combination and could be decreased by $10 \% \mathrm{CO}_{2}$ (4 incubations, $11 \mathrm{~min}, 3$-h interval) in ECs. d-e $\mathrm{H}_{2} \mathrm{O}_{2}$-induced (d) and RBD-triggered (e) production of IL-6 by ECs was diminished by $10 \% \mathrm{CO}_{2}$ (11 min, 3-h interval). The level of IL- 6 secreted into the cell culture supernatant was determined by ELISA. Dimeric intracellular IL-6 was visualised by immunoblotting with an anti-IL- 6 antibody, and the expression of this form of IL- 6 was normalised to the signal obtained with an anti-GAPDH antibody. f $\mathrm{CO}_{2}$ at a concentration of $9-12 \%$ inhibited the production of IL-6 which was induced by RBD, TNF $\alpha$ and IFN $\gamma$ combination. IL- 6 production was measured by ELISA. The results of three biological replications are presented as the mean $\pm \mathrm{SD}$ 
a

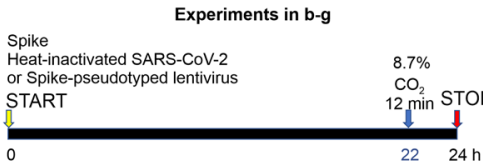

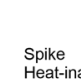

Heat-inactivated SARS-CoV-2

START

START
Experiments in $\mathrm{h}-\mathrm{k}$

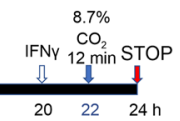

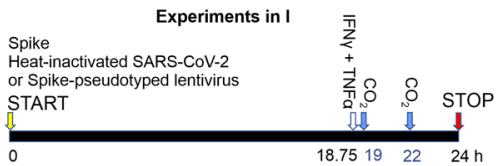

d Spike-pseudotyped lentivirus

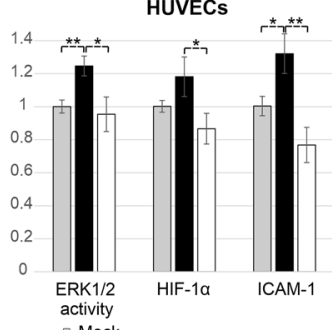

activity

- Spike-pseudotyped lentivirus

- Spike-pseudotyped lentivirus $+8.7 \% \mathrm{CO}_{2}$

9 Spike-pseudotyped lentivirus HPMECs

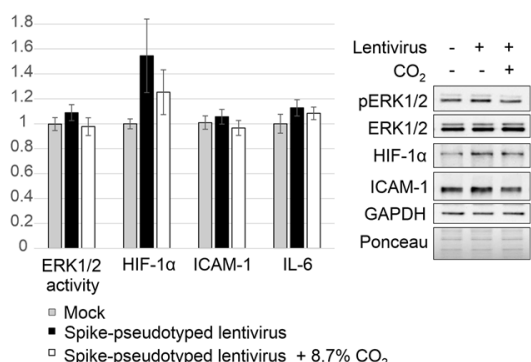

j Spike-pseudotyped lentivirus + IFNy, HPMECs

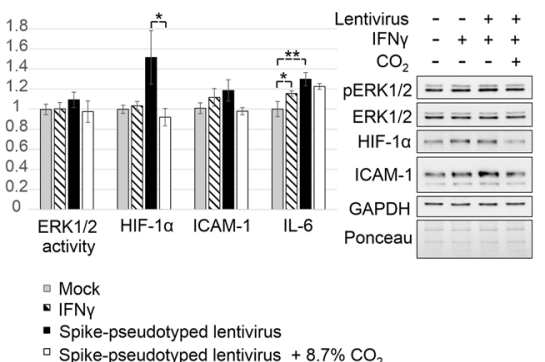

Lentivirus - + +

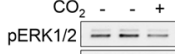
ERK $1 / 2=-$ HIF-1a $\longrightarrow-$ ICAM-1 $\ldots . \cdots$ GAPDH $-\cdots$ Ponceau k
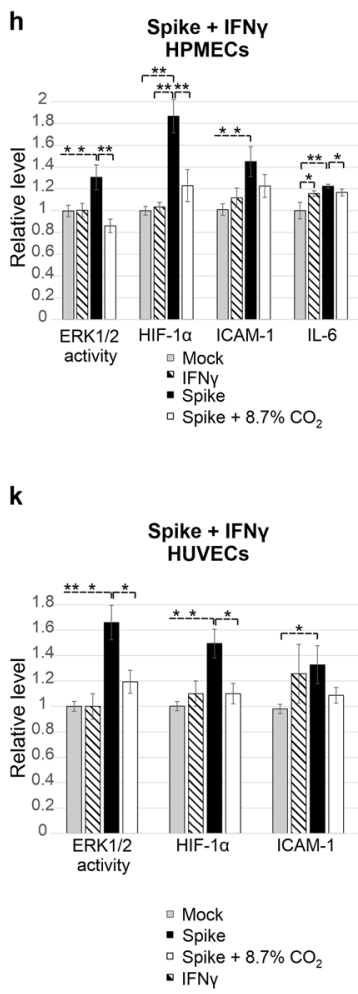

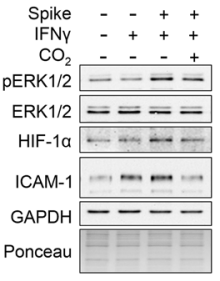

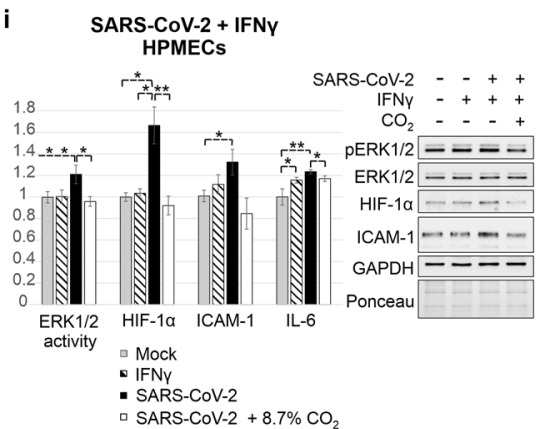

- SARS-CoV-2 $+8.7 \% \mathrm{CO}_{2}$

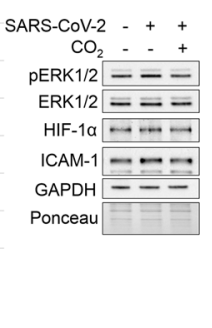

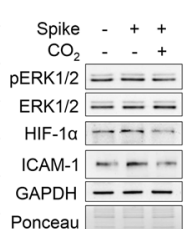

Spike -++
$\mathrm{CO}_{2}-\quad++$ ERK $1 / 2=-$ HIF-1a $\ldots-\ldots$ ICAM-1 - GAPDH ---
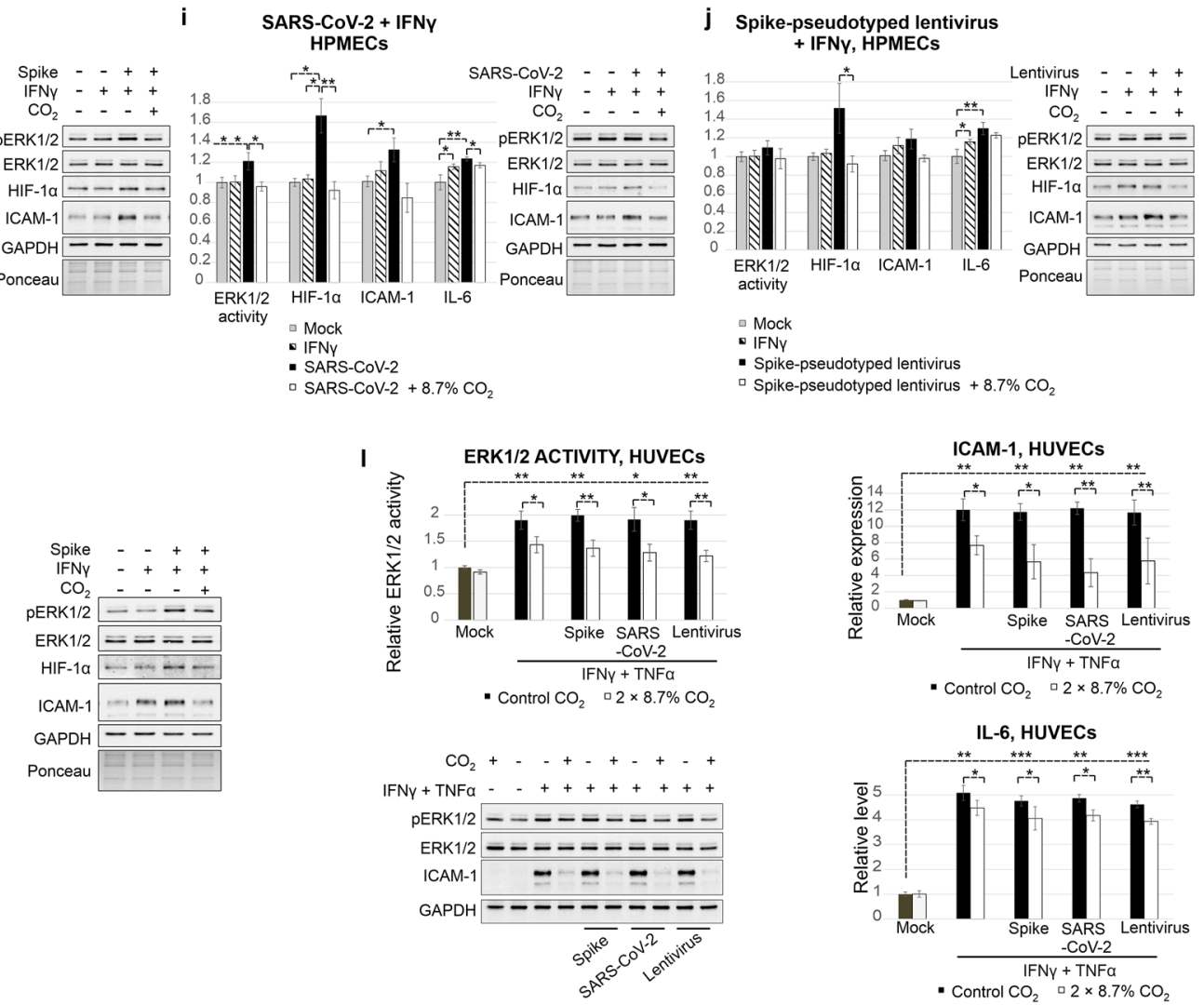

- Control $\mathrm{CO}_{2} \quad \square 2 \times 8.7 \% \mathrm{CO}_{2}$

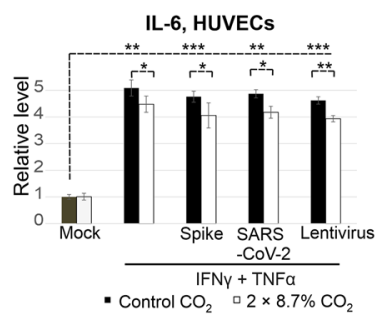


4Fig. 5 Responses to SARS-CoV-2 components and treatment with $\mathrm{CO}_{2}$ in primary ECs. ERK1/2 activity was determined by immunoblotting with an anti-phospho-ERK1/2 antibody, and protein loading was assessed by Ponceau $S$ staining and immunoblotting with antiGAPDH and anti-ERK1/2 antibodies. Changes in the expression of specific proteins were detected with anti-HIF- $1 \alpha$ and anti-ICAM-1 antibodies. IL-6 level was measured by ELISA. The means \pm SDs of three independent experiments are presented. a The scheme of the course of experiments. In b-g, ECs were incubated with mock or the indicated SARS-CoV-2 derivative for $22 \mathrm{~h}$. Then, $8.7 \% \mathrm{CO}_{2}$ was applied for $12 \mathrm{~min}$. Cells were frozen $24 \mathrm{~h}$ after the start of the experiment. In $\mathbf{h}-\mathbf{l}$, ECs were incubated with mock or the indicated SARS-CoV-2 derivative for $20 \mathrm{~h}$. Then, $7.5 \mathrm{ng} / \mathrm{ml} \mathrm{IFN} \gamma$ was added. After $2 \mathrm{~h}$, treatment with $8.7 \% \mathrm{CO}_{2}$ for 12 min was conducted. Cells were collected $24 \mathrm{~h}$ after the beginning of the experiment. b $50 \mathrm{ng} / \mathrm{ml}$ spike, HUVECs. c Heat-inactivated SARS-CoV-2, USAWA1/2020 isolate, HUVECs. A number of administered viral particles corresponded to the multiplicity of infection (MOI) of 7.5. d Spike-pseudotyped lentivirus, HUVECs. e $50 \mathrm{ng} / \mathrm{ml}$ spike, HPMECs. f Heat-inactivated SARS-CoV-2, USA/CA_CDC_5574/2020 isolate, MOI 3, HPMECs. g Spike ${ }^{\mathrm{D} 614 \mathrm{G}}$-pseudotyped lentivirus, HPMECs. h $50 \mathrm{ng} / \mathrm{ml}$ spike with $7.5 \mathrm{ng} / \mathrm{ml} \mathrm{IFN} \gamma$, HPMECs. i Heat-inactivated SARS-CoV-2, USA/CA_CDC_5574/2020 isolate with $7.5 \mathrm{ng} / \mathrm{ml}$ IFN $\gamma$, HPMECs. j Spike ${ }^{\mathrm{D} 614 \mathrm{G}}$-pseudotyped lentivirus with $7.5 \mathrm{ng} / \mathrm{ml}$ IFN $\gamma$ in HPMECs. $\mathbf{k} 50 \mathrm{ng} / \mathrm{ml}$ spike with $7.5 \mathrm{ng} / \mathrm{ml}$ IFN $\gamma$, HUVECs. 1 HUVECs were incubated with mock or the indicated SARS-CoV-2 derivative for $18 \mathrm{~h} 45 \mathrm{~min}$. Then, $7.5 \mathrm{ng} / \mathrm{ml} \mathrm{IFN} \gamma$ and $10 \mathrm{ng} / \mathrm{ml} \mathrm{TNF} \alpha$ were added. After $15 \mathrm{~min}$ and subsequently after $3 \mathrm{~h} 15 \mathrm{~min}$, the cells were treated with $8.7 \% \mathrm{CO}_{2}$ for $12 \mathrm{~min}$. Cells were collected $24 \mathrm{~h}$ after the beginning of the experiment. pERK1/2 - phosphorylated ERK1/2

SARS-CoV-2 derivatives to the levels following IFN $\gamma$ induction, in contrast with ICAM-1 and HIF-1 $\alpha$ expression levels, which were repressed to near control levels. Very high induction of ICAM-1 and IL-6 expression on synergistic action of TNF $\alpha$ and IFN $\gamma$ (also in combination with the presence of spike, heat-inactivated SARS-CoV-2 or spikepseudotyped lentivirus) can be partially repressed by two treatments with $\mathrm{CO}_{2}$ after TNF $\alpha$ and IFN $\gamma$ administration (Fig. 51).

Overall, the current work revealed that $\mathrm{CO}_{2}$ is a potent regulator of MAPK activity. The effect of its action can be tailored by adjusting the concentration and duration of the treatment.

\section{Discussion}

In the present work, we identified a novel regulatory mechanism and cross-talk between fundamental signalling pathways through the regulation of ERK $1 / 2$ by $\mathrm{CO}_{2}$. Its regulatory effect on the inflammatory response presented in this paper is only a one example of the possible applications of $\mathrm{CO}_{2}$, and our findings have much broader significance due to involvement of MAPKs in many developmental processes and oncogenesis. Accordingly, a number of MAPK inhibitors have been approved as potent drugs for the treatment of numerous diseases, including cancers. However, they cannot be fully exploited due to their toxicity. $\mathrm{CO}_{2}$, which is safe under controlled conditions, could overcome these limitations. The elucidation of the molecular basis of the action of $\mathrm{CO}_{2}$ in this paper may be the first step in broadening the use of $\mathrm{CO}_{2}$ in clinical practice, as there are many preclinical studies showing the effects of $\mathrm{CO}_{2}$, including its anti-tumour activity [29].

Despite the obvious detrimental effects of long-term exposure to elevated $\mathrm{CO}_{2}$ concentrations [30], short-term inhalation of 5-8\% $\mathrm{CO}_{2}$ as a treatment for inflammation appears to be unprecedentedly safe because $\mathrm{CO}_{2}$ is a natural compound that constantly affects the body, has transient effects and is easily removed via the lungs and kidneys. The amount of $\mathrm{CO}_{2}$ supplied by a single administration of 5-8\% $\mathrm{CO}_{2}$ is equivalent to that produced by breath holding several times for less than half a min. However, unlike breath holding, oxygen is also delivered to the lungs at the same time.

Hundreds of clinical trials have confirmed that short-term inhalation of $5 \% \mathrm{CO}_{2}$ is absolutely safe and that $\mathrm{CO}_{2}$ does not have systemic effects when inhaled at a concentration of up to $8 \%$ [31]. Inhalation of $5 \% \mathrm{CO}_{2}$ is used in magnetic resonance imaging due the potent vasodilatory ability of $\mathrm{CO}_{2}$. In psychiatry, inhalation of up to $35 \% \mathrm{CO}_{2}$ is applied to induce a panic attack, and it has been postulated that studies should be conducted with a minimum of $7.5 \% \mathrm{CO}_{2}$ since $5 \%$ $\mathrm{CO}_{2}$ causes physiological and psychological effects that are too weak [32]. On the other hand, in healthy subjects, $10 \%$ $\mathrm{CO}_{2}$ (i.e. a very high concentration) increases pulmonary artery pressure. However, inhaled $5 \% \mathrm{CO}_{2}$ reduces existing pulmonary hypertension [33]. Correspondingly, in this work, we found that $\mathrm{CO}_{2}$ activates inactive ERK1/2 and inactivates active ERK1/2.

Inhaled $\mathrm{CO}_{2}$ is effective for the treatment of febrile seizures [34], central sleep apnoea syndrome [35], and seizures in epilepsy patients [36] and counteracts central retinal artery occlusion [31]. $\mathrm{CO}_{2}$ enables oxygen to be released from haemoglobin [37]. As a result of inhalation of 2-5\% $\mathrm{CO}_{2}$, the oxygenation of the arterial blood increases, which results in better oxidation and susceptibility of tumours to radiotherapy [38]. Similarly, in infants ventilated mechanically after the Norwood procedure, administration of $\mathrm{CO}_{2}$ increases blood oxygen saturation and the supply of oxygen to tissues [39]. $\mathrm{CO}_{2}$ is not only increasingly being used for carboxytherapy in aesthetic medicine but also increasingly being administered via inhalation and baths for the treatment of kidney, cardiovascular and neurological diseases.

Although $\mathrm{CO}_{2}$ sensing seems to be a universal process among eukaryotes, currently recognised $\mathrm{HCO}_{3}{ }^{-}$sensors, namely, GCs and $\mathrm{ACs}$, are absent in many eukaryotes. Moreover, $\mathrm{CO}_{2}$ signalling pathways, which are crucial for vertebrates, are independent of GCs and ACs, including the pathways responsible for the regulation of breathing in response to changes in $\mathrm{CO}_{2}$ 
concentrations [40], $\mathrm{CO}_{2}$ sensing by olfactory sensory neurons [3], and $\mathrm{HCO}_{3}{ }^{-}$-dependent regulation of spontaneous heart rate and cardiac force development. Interestingly, the activity of AC and GC in Dictyostelium discoideum depends on DdERK2, the activation of which is independent of MEKs [41]. Yeast proteins involved in $\mathrm{CO}_{2}$ signalling are functionally closely associated with MAPKs; Sch9 kinase [42] is regulated by Hog1 MAPK, and Ptc2 is a MAPK phosphatase that dephosphorylates Hog1 [43]. Intriguingly, ERK1/2, JNK and p38 are clearly involved in carbon monoxide signalling [44].

In this work, we focused on long-term activation of ERK $1 / 2$ to clearly demonstrate the effectiveness of $\mathrm{CO}_{2}$ at the level of MAPK activity. However, activation of MAPKs in response to many factors is transient. Regarding this type of MAPK activation, the effectiveness of both MAPK inhibitors [45] and a single 10-min administration of $5 \% \mathrm{CO}_{2}$ [46] in vivo in preventing LPS-induced development of pneumonia has already been proven.

The conclusions from the present work are consistent with previous studies; $\mathrm{CO}_{2}$-induced activation of inactive ERK1/2 and inactivation of active ERK1/2 have been demonstrated in pheochromocytoma cells [47]. However, these results were not interpreted to be the direct influence of $20 \% \mathrm{CO}_{2}$ on ERK1/2 activity. More recently, Xu et al. [48] showed that ERK1/2 is inactivated by $\mathrm{CO}_{2}$ in rat skeletal muscle.

Although ERK1/2, JNK and p38 have been shown to facilitate the replication of many viruses and nuclear export of viral ribonucleoprotein complexes, the MAPK pathway that is currently attracting the most attention is the pathway involved in the regulation of proinflammatory cytokine expression. Dex is widely used in the treatment of inflammation in severe COVID-19. However, the serious conditions of patients often result from comorbidities, and contraindications to the use of dex coincide with factors that increase the risk of a severe COVID-19. In addition, among other factors, chronic obstructive pulmonary disease (COPD), cigarette smoke extract, bleomycin-induced acute lung injury and oxidative stress have been shown to cause resistance to corticosteroids in bronchial and alveolar epithelial cells. We have shown that the inhibitory effect of lower doses of dex in combination with $\mathrm{CO}_{2}$ on ERK1/2 is as marked as that of a high dose of dex. Moreover, $\mathrm{CO}_{2}$ treatment is the most effective method for inactivating ERK1/2 in epithelial cells in the presence of increased IFN $\gamma$ and TNF $\alpha$ levels, which is characteristic of severe COVID-19.

In addition to a cytokine storm, infection with SARS-CoV-2 induces ROS generation [20]. In severe COVID-19, ROS and cytokine production in the lungs is enhanced by hyperoxia (resulting from oxygen support) [49] and mechanical ventilation [50-52]. These processes exacerbate lung injury, which can be reduced by both $\mathrm{CO}_{2}$ treatment and inhibition of MAPKs [49]. $\mathrm{CO}_{2}$ clearly inhibits ROS generation in many human and mouse tissues and stimulates the production of antioxidants [53]. There are other overlapping effects of $\mathrm{CO}_{2}$ and MEK inhibitors. MAPK inhibitors [45] or 5\% $\mathrm{CO}_{2}$ inhalation for $10 \mathrm{~min}$ [46] is protective against LPS-induced pneumonia in mice. $\mathrm{CO}_{2}$ [54] and MEK inhibitors [19] attenuate the release of proinflammatory cytokines. Similarly, both synthetic MAPK inhibitors [55] and $\mathrm{CO}_{2}$ [56] counteract reperfusion and oxidative brain injury after ischaemic stroke, which is a frequent complication following SARS-CoV-2 infection. Therefore, the total $\mathrm{CO}_{2}$ concentration is lower in deceased patients than in patients who have recovered from COVID-19 [57]. In addition, it has been observed that current smoking protects against the development of severe COVID-19 symptoms [58].

\section{Conclusions}

We have shown that $\mathrm{CO}_{2}$ is a potent inhibitor of ERK1/2 activity that acts independently of cell type and proinflammatory cytokines, which is in contrast to cytokine-susceptible aspirin and dex. Unlike dex and aspirin, $\mathrm{CO}_{2}$, which readily penetrates tissues and cells and acts independently of appropriate transporters, receptors and signalling pathways, inactivates mainly overactivated ERK1/2. Thus, our study supports previous report [59]. We encourage researchers to undertake further studies on $\mathrm{CO}_{2}$ as a potential therapeutic agent for COVID-19.

Supplementary Information The online version contains supplementary material available at https://doi.org/10.1007/s00018-021-04005-3.

Acknowledgements The authors thank Mirosława Dabert and Robert Nawrot for logistic support and Aleksandra Antończyk, Adrianna Budzińska, Arkadiusz Kajdasz, Agata Michalska, Witold Nowak and Bartosz Słowikowski for providing materials.

Author contributions HG: funding acquisition, writing — original draft preparation, formal analysis, visualisation, and investigation. WJ: funding acquisition, writing — original draft preparation, writing - reviewing and editing, and formal analysis. LG: conceptualisation, funding acquisition, writing — original draft preparation, writing—reviewing and editing, formal analysis, investigation, and visualisation.

Funding This work was supported by the National Science Center, Poland [Grant numbers 2015/19/D/NZ3/00479 to HG, 2016/21/B/ NZ3/00333 to W.J. and 2011/01/D/NZ3/02068 to ŁG].

Availability of data and material All the data generated or analysed during this study are included in this published article and its supplementary information files. Raw images generated during the current study are available from the corresponding author on reasonable request.

Code availability Not applicable.

\section{Declarations}

Conflict of interest The authors declare that they have no conflict of interest. 
Ethical approval The experiments comply with the current laws of Poland.

Open Access This article is licensed under a Creative Commons Attribution 4.0 International License, which permits use, sharing, adaptation, distribution and reproduction in any medium or format, as long as you give appropriate credit to the original author(s) and the source, provide a link to the Creative Commons licence, and indicate if changes were made. The images or other third party material in this article are included in the article's Creative Commons licence, unless indicated otherwise in a credit line to the material. If material is not included in the article's Creative Commons licence and your intended use is not permitted by statutory regulation or exceeds the permitted use, you will need to obtain permission directly from the copyright holder. To view a copy of this licence, visit http://creativecommons.org/licenses/by/4.0/.

\section{References}

1. Dagnell M, Cheng Q, Rizvi SHM et al (2019) Bicarbonate is essential for protein-tyrosine phosphatase 1B (PTP1B) oxidation and cellular signaling through EGF-triggered phosphorylation cascades. J Biol Chem 294:12330-12338. https://doi.org/10.1074/ jbc.RA119.009001

2. Chen Y, Cann MJ, Litvin TN et al (2000) Soluble adenylyl cyclase as an evolutionarily conserved bicarbonate sensor. Science 289:625-628. https://doi.org/10.1126/science.289.5479.625

3. Kenemuth JK, Hennessy SP, Hanson RJ et al (2013) Investigation of nasal $\mathrm{CO}_{2}$ receptor transduction mechanisms in wild-type and GC-D knockout mice. Chem Senses 38:769-781. https://doi.org/ 10.1093/chemse/bjt044

4. Cargnello M, Roux PP (2011) Activation and function of the MAPKs and their substrates, the MAPK-activated protein kinases. Microbiol Mol Biol Rev 75:50-83. https://doi.org/10.1128/mmbr. 00031-10

5. Roskoski R (2012) ERK1/2 MAP kinases: structure, function, and regulation. Pharmacol Res 66:105-143. https://doi.org/10.1016/j. phrs.2012.04.005

6. Lin C-I, Tsai C-H, Sun Y-L et al (2018) Instillation of particulate matter 2.5 induced acute lung injury and attenuated the injury recovery in ACE2 knockout mice. Int J Biol Sci 14:253-265. https://doi.org/10.7150/ijbs.23489

7. Li Y, Zeng Z, Cao Y et al (2016) Angiotensin-converting enzyme 2 prevents lipopolysaccharide-induced rat acute lung injury via suppressing the ERK1/2 and NF- $\kappa B$ signaling pathways. Sci Rep 6:27911. https://doi.org/10.1038/srep27911

8. Patra T, Meyer K, Geerling L et al (2020) SARS-CoV-2 spike protein promotes IL-6 trans-signaling by activation of angiotensin II receptor signaling in epithelial cells. PLoS Pathog. https://doi. org/10.1371/journal.ppat.1009128

9. Gałgańska H, Gałgański Ł (2020) Mitogen-activated protein kinases are carbon dioxide receptors in plants. bioRxiv. https:// doi.org/10.1101/2020.05.09.086116

10. Walkey AJ, Farber HW, O'Donnell C et al (2010) The accuracy of the central venous blood gas for acid-base monitoring. J Intensive Care Med 25:104-110. https://doi.org/10.1177/0885066609 356164

11. Jarmuszkiewicz W, Dominiak K, Galganski L et al (2020) Lung mitochondria adaptation to endurance training in rats. Free Radic Biol Med 161:163-174. https://doi.org/10.1016/j.freeradbiomed. 2020.10.011

12. Gałgańska H, Antoniewicz M, Budzińska M et al (2010) VDAC contributes to mRNA levels in Saccharomyces cerevisiae cells by the intracellular reduction/oxidation state dependent and independent mechanisms. J Bioenerg Biomembr 42:483-489. https://doi.org/10.1007/s10863-010-9315-6

13. Livak KJ, Schmittgen TD (2001) Analysis of relative gene expression data using real-time quantitative PCR and the 2(-Delta Delta $\mathrm{C}(\mathrm{T})$ ) method. Methods 25:402-408. https://doi.org/10.1006/ meth.2001.1262

14. Huertas A, Montani D, Savale L et al (2020) Endothelial cell dysfunction: a major player in SARS-CoV-2 infection (COVID19)? Eur Respir J 56:2001634. https://doi.org/10.1183/13993003. 01634-2020

15. Pons S, Fodil S, Azoulay E, Zafrani L (2020) The vascular endothelium: the cornerstone of organ dysfunction in severe SARS-CoV-2 infection. Crit Care 24:353. https://doi.org/10.1186/ s13054-020-03062-7

16. Fürst R, Zahler S, Vollmar AM (2008) Dexamethasone-induced expression of endothelial mitogen-activated protein kinase phosphatase-1 involves activation of the transcription factors activator protein-1 and $3^{\prime}, 5^{\prime}$-cyclic adenosine $5^{\prime}$-monophosphate response element-binding protein and the generation of reactive oxygen species. Endocrinology 149:3635-3642. https://doi.org/10.1210/ en.2007-1524

17. Schimmel L, Chew KY, Stocks C et al (2021) Endothelial cells are not productively infected by SARS-CoV-2. Clin Transl Immunol. https://doi.org/10.1002/cti2.1350

18. Hsu AC-Y, Wang G, Reid AT et al (2020) SARS-CoV-2 Spike protein promotes hyper-inflammatory response that can be ameliorated by Spike-antagonistic peptide and FDA-approved ER stress and MAP kinase inhibitors in vivo. bioRxiv. https://doi.org/10. 1101/2020.09.30.317818

19. Zhou L, Huntington K, Zhang S et al (2020) MEK inhibitors reduce cellular expression of ACE2, pERK, $\mathrm{pRb}$ while stimulating NK-mediated cytotoxicity and attenuating inflammatory cytokines relevant to SARS-CoV-2 infection. Oncotarget 11:4201-4223. https://doi.org/10.18632/oncotarget.27799

20. Codo AC, Davanzo GG, de Monteiro LB et al (2020) Elevated glucose levels favor SARS-CoV-2 infection and monocyte response through a HIF-1 $\alpha /$ glycolysis-dependent axis. Cell Metab 32:437446.e5. https://doi.org/10.1016/j.cmet.2020.07.007

21. Koziel A, Sobieraj I, Jarmuszkiewicz W (2015) Increased activity of mitochondrial uncoupling protein 2 improves stress resistance in cultured endothelial cells exposed in vitro to high glucose levels. Am J Physiol Hear Circ Physiol 309:H147-H156. https://doi. org/10.1152/ajpheart.00759.2014

22. Ziegler CGK, Allon SJ, Nyquist SK et al (2020) SARS-CoV-2 receptor ACE2 is an interferon-stimulated gene in human airway epithelial cells and is detected in specific cell subsets across tissues. Cell 181:1016-1035.e19. https://doi.org/10.1016/j.cell.2020. 04.035

23. Pons S, Fodil S, Azoulay E, Zafrani L (2020) The vascular endothelium: the cornerstone of organ dysfunction in severe SARS-CoV-2 infection. Crit Care. https://doi.org/10.1186/ s13054-020-03062-7

24. Steinke JW, Liu L, Huyett P et al (2013) Prominent role of IFN- $\gamma$ in patients with aspirin-exacerbated respiratory disease. J Allergy Clin Immunol. https://doi.org/10.1016/j.jaci.2013.05.008

25. Nishio T, Usami M, Awaji M et al (2016) Dual effects of acetylsalicylic acid on ERK signaling and Mitf transcription lead to inhibition of melanogenesis. Mol Cell Biochem 412:101-110. https://doi.org/10.1007/s11010-015-2613-x

26. Homma T, Kato A, Hashimoto $\mathrm{N}$ et al (2004) Corticosteroid and cytokines synergistically enhance toll-like receptor 2 expression in respiratory epithelial cells. Am J Respir Cell Mol Biol 31:463469. https://doi.org/10.1165/rcmb.2004-0161OC

27. Li L, Goleva E, Hall CF et al (2004) Superantigen-induced corticosteroid resistance of human $\mathrm{T}$ cells occurs through activation of the mitogen-activated protein kinase kinase/extracellular 
signal-regulated kinase (MEK-ERK) pathway. J Allergy Clin Immunol 114:1059-1069. https://doi.org/10.1016/j.jaci.2004. 08.005

28. Pankov R, Yamada KM (2002) Fibronectin at a glance. J Cell Sci 115:3861-3863. https://doi.org/10.1242/jcs.00059

29. Onishi Y, Kawamoto T, Ueha T et al (2012) Transcutaneous application of carbon dioxide $\left(\mathrm{CO}_{2}\right)$ induces mitochondrial apoptosis in human malignant fibrous histiocytoma in vivo. PLoS ONE. https://doi.org/10.1371/journal.pone.0049189

30. Azuma K, Kagi N, Yanagi U, Osawa H (2018) Effects of low-level inhalation exposure to carbon dioxide in indoor environments: a short review on human health and psychomotor performance. Environ Int 121:51-56. https://doi.org/10.1016/j.envint.2018.08. 059

31. Schmetterer L, Lexer F, Findl O et al (1996) The effect of inhalation of different mixtures of $\mathrm{O}_{2}$ and $\mathrm{CO}_{2}$ on ocular fundus pulsations. Exp Eye Res 63:351-355. https://doi.org/10.1006/exer. 1996.0125

32. Bailey JE, Argyropoulos SV, Kendrick AH, Nutt DJ (2005) Behavioral and cardiovascular effects of $7.5 \% \mathrm{CO}_{2}$ in human volunteers. Depress Anxiety. https://doi.org/10.1002/DA.20048

33. Chuang I-C, Yang R-C, Chou S-H et al (2011) Effect of carbon dioxide inhalation on pulmonary hypertension induced by increased blood flow and hypoxia. Kaohsiung J Med Sci 27:336343. https://doi.org/10.1016/j.kjms.2011.03.007

34. Ohlraun S, Wollersheim T, Weiß C et al (2013) CARbon DIoxide for the treatment of Febrile seizures: rationale, feasibility, and design of the CARDIF-study. J Transl Med 11:157. https://doi. org/10.1186/1479-5876-11-157

35. Szollosi I, Jones M, Morrell $\mathrm{M}$ et al (2004) Effect of $\mathrm{CO}_{2}$ inhalation on central sleep apnea and arousals from sleep. Respiration. https://doi.org/10.1159/000080634

36. Tolner EA, Hochman DW, Hassinen P et al (2011) Five percent $\mathrm{CO}_{2}$ is a potent, fast-acting inhalation anticonvulsant. Epilepsia 52:104-114. https://doi.org/10.1111/j.1528-1167.2010.02731.x

37. Sakai Y, Miwa M, Oe K et al (2011) A novel system for transcutaneous application of carbon dioxide causing an "artificial Bohr effect" in the human body. PLoS ONE. https://doi.org/10.1371/ journal.pone.0024137

38. Baddeley H, Brodrick PM, Taylor NJ et al (2000) Gas exchange parameters in radiotherapy patients during breathing of $2 \%, 3.5 \%$ and 5\% carbogen gas mixtures. Br J Radiol 73:1100-1104. https:// doi.org/10.1259/bjr.73.874.11271904

39. Bradley SM, Simsic JM, Atz AM (2001) Hemodynamic effects of inspired carbon dioxide after the Norwood procedure. Ann Thorac Surg 72:2084-2088. https://doi.org/10.1016/s0003-4975(01) 03169-1

40. Gonçalves CM, Mulkey DK (2018) Bicarbonate directly modulates activity of chemosensitive neurons in the retrotrapezoid nucleus. J Physiol 596:4033-4042. https://doi.org/10.1113/JP276 104

41. Segall JE, Kuspa A, Shaulsky G et al (1995) A MAP kinase necessary for receptor-mediated activation of adenylyl cyclase in Dictyostelium. J Cell Biol 128:405-413. https://doi.org/10.1083/jcb. 128.3.405

42. Pohlers S, Martin R, Krüger T et al (2017) Lipid signaling via Pkh1/2 regulates fungal $\mathrm{CO}_{2}$ sensing through the kinase Sch9. MBio. https://doi.org/10.1128/mBio.02211-16

43. Warmka J, Hanneman J, Lee J et al (2001) Ptc1, a type 2C Ser/ Thr phosphatase, inactivates the HOG pathway by dephosphorylating the mitogen-activated protein kinase Hog1. Mol Cell Biol 21:51-60. https://doi.org/10.1128/MCB.21.1.51-60.2001

44. Otterbein LE, Zuckerbraun BS, Haga M et al (2003) Carbon monoxide suppresses arteriosclerotic lesions associated with chronic graft rejection and with balloon injury. Nat Med 9:183-190. https://doi.org/10.1038/nm817
45. Schuh K, Pahl A (2009) Inhibition of the MAP Kinase ERK protects from lipopolysaccharide-induced lung injury. Biochem Pharmacol. https://doi.org/10.1016/J.BCP.2009.03.012

46. Tang S-E, Wu S-Y, Chu S-J et al (2019) Pre-treatment with tenminute carbon dioxide inhalation prevents lipopolysaccharideinduced lung injury in mice via down-regulation of toll-like receptor 4 expression. Int J Mol Sci. https://doi.org/10.3390/ijms2 0246293

47. Kuo NT, Agani FH, Haxhiu MA, Chang CH (1998) A possible role for protein kinase $\mathrm{C}$ in $\mathrm{CO} 2 / \mathrm{H}+$-induced c-fos mRNA expression in PC12 cells. Respir Physiol 111:127-135. https://doi.org/ 10.1016/S0034-5687(97)00115-1

48. Xu Y-J, Elimban V, Dhalla NS (2017) Suppression of phosphorylated MAPK and caspase 3 by carbon dioxide. Mol Cell Biochem 436:23-28. https://doi.org/10.1007/s11010-017-3073-2

49. Parinandi NL, Kleinberg MA, Usatyuk PV et al (2003) Hyperoxia-induced $\mathrm{NAD}(\mathrm{P}) \mathrm{H}$ oxidase activation and regulation by map kinases in human lung endothelial cells. Am J Physiol Lung Cell Mol Physiol 284:L26-L38

50. Helmerhorst HJF, Schouten LRA, Wagenaar GTM et al (2017) Hyperoxia provokes a time- and dose-dependent inflammatory response in mechanically ventilated mice, irrespective of tidal volumes. Intensive Care Med Exp. https://doi.org/10.1186/ s40635-017-0142-5

51. Chiumello D, Pristine G, Slutsky AS (1999) Mechanical ventilation affects local and systemic cytokines in an animal model of acute respiratory distress syndrome. Am J Respir Crit Care Med 160:109-116. https://doi.org/10.1164/ajrccm.160.1.9803046

52. Dhanireddy S, Altemeier WA, Matute-Bello G et al (2006) Mechanical ventilation induces inflammation, lung injury, and extra-pulmonary organ dysfunction in experimental pneumonia. Lab Invest 86:790-799. https://doi.org/10.1038/labinvest.37004 40

53. Dogliotti G, Galliera E, Iorio E et al (2011) Effect of immersion in $\mathrm{CO}_{2}$-enriched water on free radical release and total antioxidant status in peripheral arterial occlusive disease. Int Angiol 30:12-17

54. Kimura D, Totapally BR, Raszynski A et al (2008) The effects of $\mathrm{CO}_{2}$ on cytokine concentrations in endotoxin-stimulated human whole blood. Crit Care Med 36:2823-2827. https://doi.org/10. 1097/CCM.0b013e318186f556

55. Namura $S$, Iihara $K$, Takami $S$ et al (2001) Intravenous administration of MEK inhibitor U0126 affords brain protection against forebrain ischemia and focal cerebral ischemia. Proc Natl Acad Sci USA 98:11569-11574. https://doi.org/10.1073/pnas.181213498

56. Yang WC, Wang Q, Chi LT et al (2019) Therapeutic hypercapnia reduces blood-brain barrier damage possibly via protein kinase $\mathrm{C} \epsilon$ in rats with lateral fluid percussion injury. J Neuroinflammation. https://doi.org/10.1186/s12974-019-1427-2

57. Chen $\mathrm{T}, \mathrm{Wu} \mathrm{D}, \mathrm{Chen} \mathrm{H}$ et al (2020) Clinical characteristics of 113 deceased patients with coronavirus disease 2019: retrospective study. BMJ. https://doi.org/10.1136/bmj.m1091

58. Changeux JP, Amoura Z, Rey FA, Miyara M (2020) A nicotinic hypothesis for Covid-19 with preventive and therapeutic implications. Comptes Rendus 343:33-39. https://doi.org/10.32388/ FXGQSB.2

59. El-Betany AMM, Behiry EM, Gumbleton M, Harding KG (2020) Humidified warmed $\mathrm{CO}_{2}$ treatment therapy strategies can save lives with mitigation and suppression of SARS-CoV-2 infection: an evidence review. Front Med 7: https://doi.org/10.3389/fmed. 2020.594295

Publisher's Note Springer Nature remains neutral with regard to jurisdictional claims in published maps and institutional affiliations. 